\title{
The Role of Protein Misfolding and Tau Oligomers (TauOs) in Alzheimer's Disease (AD)
}

\author{
Barbara Mroczko ${ }^{1,2, *}$, Magdalena Groblewska ${ }^{2}$ and Ala Litman-Zawadzka ${ }^{1}$ \\ 1 Department of Neurodegeneration Diagnostics, Medical University of Białystok, 15-269 Białystok, Poland; \\ ala.litman-zawadzka@umb.edu.pl \\ 2 Department of Biochemical Diagnostics, University Hospital of Białystok, 15-269 Białystok, Poland; \\ magdalena.groblewska@umb.edu.pl \\ * Correspondence: mroczko@umb.edu.pl
}

Received: 30 August 2019; Accepted: 16 September 2019; Published: 20 September 2019

\begin{abstract}
Although the causative role of the accumulation of amyloid $\beta 1-42$ (A $\beta 42)$ deposits in the pathogenesis of Alzheimer's disease (AD) has been under debate for many years, it is supposed that the toxicity soluble oligomers of Tau protein (TauOs) might be also the pathogenic factor acting on the initial stages of this disease. Therefore, we performed a thorough search for literature pertaining to our investigation via the MEDLINE/PubMed database. It was shown that soluble TauOs, especially granular forms, may be the most toxic form of this protein. Hyperphosphorylated TauOs can reduce the number of synapses by missorting into axonal compartments of neurons other than axon. Furthermore, soluble TauOs may be also responsible for seeding Tau pathology within AD brains, with probable link to $A \beta O$ s toxicity. Additionally, the concentrations of TauOs in the cerebrospinal fluid (CSF) and plasma of AD patients were higher than in non-demented controls, and revealed a negative correlation with mini-mental state examination (MMSE) scores. It was postulated that adding the measurements of TauOs to the panel of CSF biomarkers could improve the diagnosis of AD.
\end{abstract}

Keywords: Alzheimer's disease; tau oligomers; neurodegeneration; protein misfolding; tauopathy; CSF; plasma; serum

\section{Introduction}

\subsection{Protein Misfolding}

Protein folding is a physical process of the formation a highly organized molecular structure, with a characteristic, thermodynamically stable conformation, by a polypeptide chain [1]. Immediately after translation, the biosynthesis of proteins must be completed by post-translational processes. Proteins in the 'native' state form an unstructured polypeptide chain, which exhibits non-stable spatial structure. Their correct three-dimensional conformation is a result of the interactions between neighboring amino acids (AA). It is thought that AA sequence is the main determinant of the native structure of a given protein [2], although some observations indicate that the natural structure of proteins present in a living cell may also depend on interactions with other proteins or nucleic acids [1]. It should be emphasized that conformation of proteins is required for their physiological role and biological activity, whereas inappropriate spatial structure of given protein may lead to the formation of a molecule with altered biochemical and physical properties.

It was demonstrated that misfolding of proteins may be the result of various pathological processes, including mutations in the amino acid sequence, especially single-point dominant-negative mutations of the gene encoding the protein, its disturbed post-translational processing as well as trauma, ischemia, 
or oxidative stress [3]. Incorrect protein folding can also be due to a disruption of the normal folding process by external factors [4]. Single point mutations lead to the changes of conformation in the protein molecule and their polymerization. This mechanism is observed in sickle cell anemia [5], where $\beta$-globulin chains polymerize within the deoxygenated environment of tissue capillaries and cause the decrease in the elasticity of red blood cells [6]. Another example of diseases related to aberrant protein folding may be epidermolysis bullosa simplex, where the mutant forms of the keratin KRT5 and KRT14 antagonize the function of the wild-type protein, causing protein aggregation, resulting in harmful blistering of the skin in response to injury, particularly mechanical stress [7]. Incorrect protein folding occurs also in case of transthyretin (TTR), which normally is the primary carrier of thyroxine and a transporter of retinol (reviewed by [8]). While the active form of TTR is a tetramer, certain point mutations may destabilize its molecule, which results in the accumulation of TTR monomers and seeding amyloid formation. Misfolded forms of TTR include wild-type TTR (ATTRwt) or variant amyloidogenic TTR (ATTRv). The latter form is related to familial amyloid polyneuropathy (TTR-FAP), which is characterized by pain, muscular weakness and autonomic dysfunction. ATTRwt amyloidosis is considered as the cause of cardiomyopathy and, more recently, related to carpal tunnel syndrome. An introduction of disease-modifying therapies for this disease attracts many researchers [8]. A single-point mutation may be associated with favoring an intermediate form in the folding process as a more stable, the lowest energy state, over the properly folded protein. Therefore, stable protein aggregates can accumulate and disrupt cellular processes.

Protein misfolding and accumulation may occur within various tissues and cells. In neurons, the consequence of this accumulation are senile plaques, neurofibrillary tangles (NFTs), Pick bodies, Lewy bodies and other pathological changes in neuronal structure [9]. Amyloids may be the examples of such abnormal, misfolded proteinaceous structures. They are harmful, starch-like molecules organized in a supramolecular arrangement known as a cross- $\beta$ structure, which arise from many different proteins and accumulate within various tissues [10]. Amyloids constitute of many copies of proteins folded into a shape allowing their molecules for sticking together. They form elongated fibrils consisting of $\beta$-sheet structures of separate monomers, which are positioned perpendicularly to the fibril axis and stacked strictly above each other. Moreover, identical polypeptides can fold into multiple distinct amyloid conformations. Interestingly, some amyloids may have physiological functions, such as formation of bacterial fimbriae, or hormone release and pigment deposition in human body [11].

The aggregation of proteins into amyloid fibrils and their subsequent deposition into plaques and intracellular inclusions is the characteristic feature of amyloid disease. Pathological amyloids are generated from normal proteins, when they lose their physiological functions and form fibrous deposits within tissues or intracellularly. The deposition of abnormal proteins can lead to a disruption of a normal function of organs. These changed proteins may even exert a toxic influence on cells and tissues, as it is seen in prion proteins [12]. The misfolding of proteins can trigger the further misfolding of other proteins and their accumulation into another aggregates or oligomers. It is known that certain amyloid proteins, called prions (for protein and infection), are known as contagious agents. The normal, 209 amino acids and $35 \mathrm{kDa}$ form of the protein is called $\mathrm{PrP}^{\mathrm{C}}$ and is found on the cell membranes. The physiological function of the prion protein remains poorly understood. It was found in animal models that the cleavage of PrP proteins in peripheral nerves causes the activation of myelin repair in Schwann cells, whereas the lack of PrP may cause their demyelination [13]. The infectious isoform of $\mathrm{PrP}$, called $\mathrm{PrP}^{\mathrm{Sc}}$, can act as a pattern to convert other non-infectious proteins into their infectious form [14]. Moreover, prion proteins are able to accumulate in stable aggregates within infected tissues, leading to their damage and cell death [15].

The accumulation and deposition of amyloid fibrils described as amyloidosis, is associated with many pathological conditions associated with ageing. What is more, amyloids may be the pathogenic forms of various proteins and polypeptides that can be linked with the development of more than 50 human diseases, known as amyloidoses including neurodegenerative diseases (NDs) $[16,17]$. Specifically, aggregated proteins are associated with prion-related disorders, such as 
bovine spongiform encephalopathy (BSE), also known as mad cow disease, or Creutzfeldt-Jakob disease (CJD). Furthermore, Alzheimer's disease (AD), TTR-FAP and familial amyloid cardiomyopathy caused by hereditary transthyretin amyloidosis belong to amyloid-related illnesses, whereas Huntington's (HD) and Parkinson's disease (PD) are linked to intracellular aggregation of another misfolded proteins - huntingtin and alpha-synuclein, respectively.

\subsection{Pathological Changes in Alzheimer's Disease}

For over than a century, since its description by Alois Alzheimer [18], the senile plaques within patients' brain composed of amyloid beta $(\mathrm{A} \beta)$ and NFTs of Tau protein have been considered as the hallmark pathological features of $\mathrm{AD}$ [19]. The role of the accumulation of $\mathrm{A} \beta$ in $\mathrm{AD}$ has been widely discussed (for review see: [20]). It is believed that $\mathrm{AD}$ pathology is initiated by $\mathrm{A} \beta$, especially the most amyloidogenic form $A \beta_{1-42}$. It is also known that in $A D$ this peptide may be present in various, antigenically distinct conformations, including monomeric and fibrillary forms, as well as oligomers of amyloid $\beta$ peptide (A $\beta$ Os) [21,22]. Currently, it is supposed that these soluble oligomers of $A \beta$, but not fibrillar $A \beta 42$ accumulated within neuritic plaques, may be responsible for the toxic activity of $A \beta$, already on a very early stage of $A D$, perhaps even initiating pathological cascade. $A \beta O$ toxicity includes loss of synapses, which is observed already in the earliest stages of AD [23], disruption of synaptic transmission, inhibition of long-term potentiation (LTP) and enhanced long-term synaptic depression (LTD) in the brain regions responsible for memory [24]. Moreover, is seems that intracellular soluble $\mathrm{A} \beta \mathrm{O}$ s may contribute to the progressive nature of $\mathrm{AD}$, spreading in a prion-like manner and can be transmitted between neurons, not only from one region to another within the brain, but it is even supposed that they might be transmitted between people [25].

Although convincing, the $\mathrm{A} \beta \mathrm{Os} \mathrm{s}^{\prime}$ hypothesis has some limitations, that do not allow for explanation of known pathological processes in $\mathrm{AD}$. One of them is that $\mathrm{A} \beta \mathrm{O}$ s are not homogenous species. $\mathrm{A} \beta \mathrm{Os}^{\prime}$ molecular weight, morphology and conformation are highly variegated, ranging from small, dimeric molecules about $4 \mathrm{kDa}$, through trimers, and low molecular weight (LMW) and high molecular weight (HMW) oligomers up to protofibrils and fibrils with molecular weight over $100 \mathrm{kDa}$. Such a phenotypic heterogeneity implies also a clinical and neuropathological diversity of $\mathrm{AD}$, as well as variegated distribution of $A \beta O s$ [25]. Moreover, binding of $A \beta O$ s to cell membranes may be mediated by over twenty various proteins on the neuronal cell surface acting as $\mathrm{A} \beta \mathrm{O}$ receptors (reviewed by [26]). Despite such big variety of putative receptors for oligomers, no single candidate receptor has been yet shown to be sufficient and essential for all features of $\mathrm{A} \beta \mathrm{O}$-mediated toxicity. This indicates that $\mathrm{A} \beta \mathrm{Os}$ are 'multifunctional' and may have variegated toxic influence as drivers of neurodegeneration in $\mathrm{AD}$. Therefore, it seems that $\mathrm{A} \beta \mathrm{O}$ s hypothesis of $\mathrm{AD}$ etiology in not sufficient and does not explain all aspects of this disease. It may be confirmed by the fact that anti- $A \beta$ therapies of $A D$, turned out to be not effective. As it was mentioned above, the progression of AD depends not only on A $\beta O$ s, and may be complicated and accelerated by other pathologies, such as inflammation or Tau pathology.

Therefore, it was proposed that amyloid cascade is not the only pathway to AD (discussed by [27-29]). Although progressive deposition Tau protein in AD brain is preceded by the accumulation of $A \beta$, there is another hypothesis that assumes the abnormalities in the Tau protein are the first step in the cascade of pathological events in AD [30]. Additionally, this accumulation of Tau protein may contribute to pathological changes observed not only in AD, but also in other NDs, called tauopathies. Consequently, the aim of this review is to discuss the role of misfolded Tau protein in AD.

\section{Materials and Methods}

\section{Literature Search and Data Extraction}

We have performed a comprehensive literature search using the PubMed electronic database from August 2018 to August 2019, with the following search strategy (key words sets): 'Alzheimer's disease AND Tau oligomers' (612 items); 'CSF AND Alzheimer's disease AND Tau oligomers' (31 studies) as 
well as 'plasma OR serum AND Alzheimer's disease AND Tau oligomers' (31 papers). A total 674 records were found. Then we excluded 509 articles not containing data useful for our analysis. As a result, the remained 165 full-text articles and two books were assessed for eligibility. In the final step, we excluded 47 review papers, and so 113 original publications and 3 meta-analyses were included in the study. (Figure 1-PRISMA 2009 Flow Diagram).

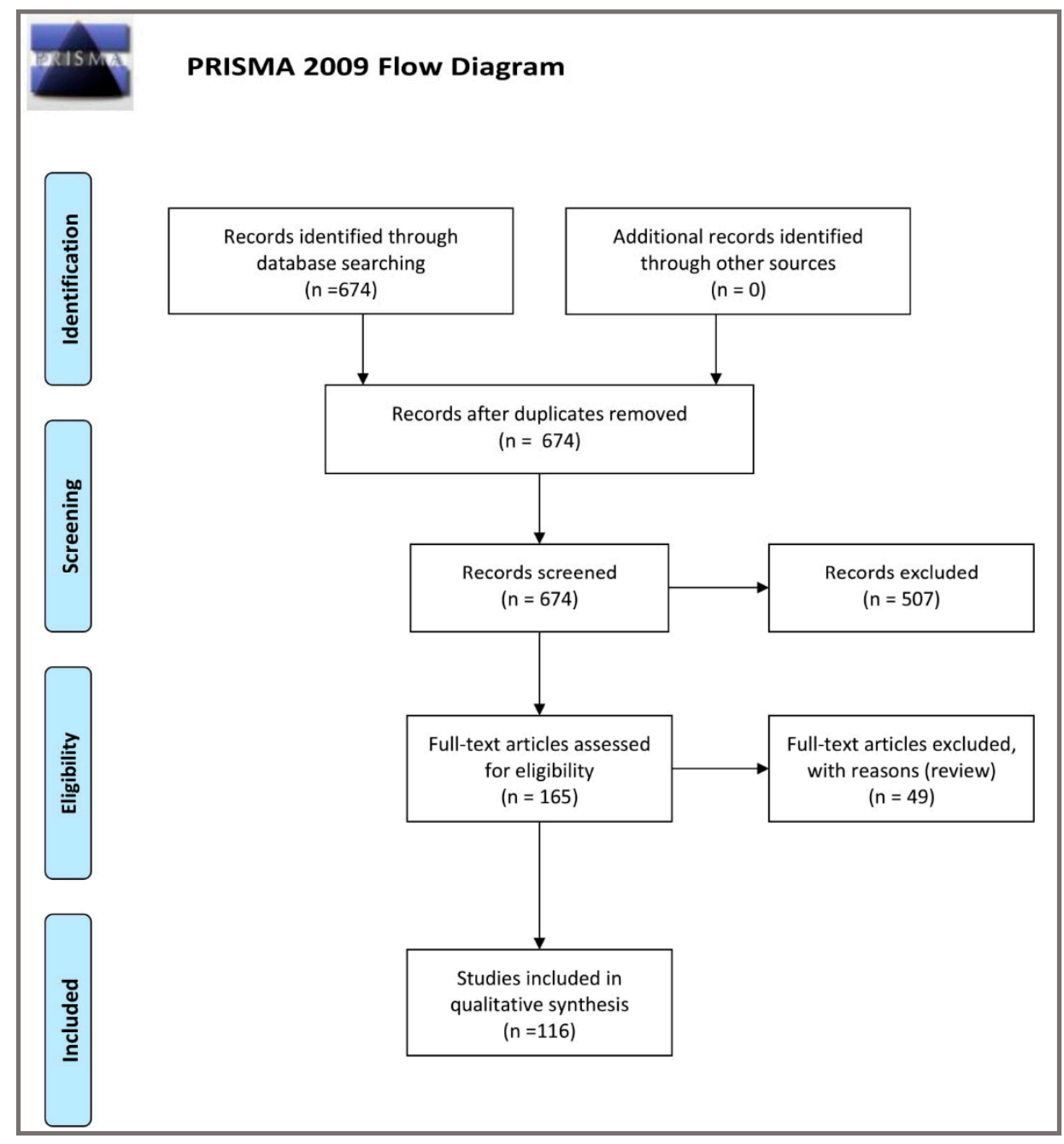

Figure 1. Schematic illustration of articles included in the review manuscript [31].

\section{Tau Protein}

\subsection{Tau Protein Gene and Its Transcription Products}

Microtubule (MT) associated Tau protein is a heat stable protein of molecular weight approximately $60 \mathrm{kDa}$ and 352-441 AA, which belongs to the family of microtubule-associated proteins (MAP) and is expressed mainly in neurons [32,33]. The gene mapt for Tau protein is located at locus 17q21 and includes at least 16 exons, which of them exons 0 and 14 are transcribed but not translated [34]. Two specific regions, N-terminal and C-terminal halves, may be distinguished in the primary structure of Tau protein, with $\mathrm{N}$-terminal part showing higher variability among Tau proteins from different species [35]. These two major domains are divided on the basis of their microtubule interactions and AA character: C-terminal half is described as an 'assembly domain' whereas the $\mathrm{N}$-terminal half is a 'projection domain'. Furthermore, Tau comprises of four regions within its molecule: N-terminal region; proline-rich domain (PRD) which is located in the central region of this protein; region responsible for binding of Tau with MTs (microtubule binding domain, MBD), and C-terminal domain [36]. N-terminal 
region is encoded by exons 1-5, while exons 2 and 3 encode the 29 amino acids inserts in $\mathrm{N}$-terminal region of Tau, which determine isoforms of this protein: $0 \mathrm{~N}$ (no inserts), $1 \mathrm{~N}$ (one insert encoded by exon 2), 2N (two inserts encoded both by exons 2 and 3). Exon 3 depends on the presence of exon 2, thus it is not transcribed in the absence of exon 2. Furthermore, the expression of exons 4A, 6 and 8 is limited to peripheral nervous system (PNS), encoding 'big Tau', a series of larger Tau proteins with molecular mass of 100-120 kDa [37]. This 'big-Tau' protein sequence is identical to the longest of small Tau isoforms, but includes an additional $254 \mathrm{AA}$ insert in the N-terminal half of its molecule [37]. Exon 7 and the first half of exon 9 encode PRD, while MBD is encoded by exons 9-12. MBD includes four repeats, R1, R2, R3 and R4 (isoform $4 \mathrm{R}$ ) or three repeats (R1, R3 and R4) (isoform 3R) of approximately 32 AA residues sequence. These residues include semi-conservative motif KXGS, where serine may be phosphorylated [38]. Number of these repeats depends on the presence of exon 10. Isoform $4 R$, including four repeats, is synthesized in the presence of this exon, whereas isoform $3 R$ (three repeats) is produced when this exon is not expressed. The latter, C-terminal region is encoded by exon 13 [36,39] (Figure 2).

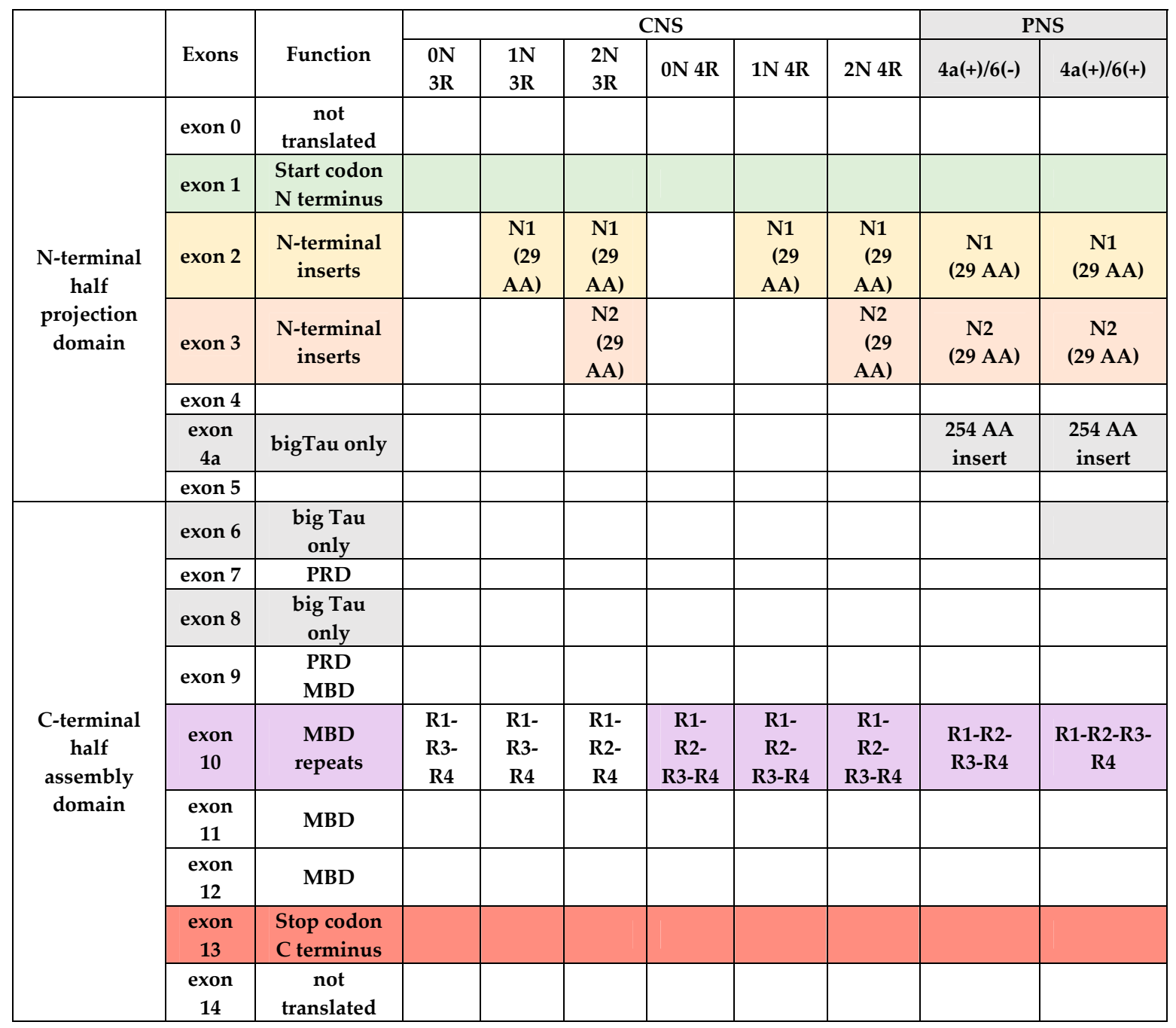

Figure 2. Schematic structure of Tau molecule in central (CNS) and peripheral nervous system (PNS) in relation to alternative splicing of exons. Abbreviations; PRD—proline rich domain, MBD—microtubule binding domain, AA—aminoacids.

Moreover, there is a polymorphism of haplogroups, which differ in their orientation within the mapt gene: an inversion (H1) or non-inversion (H2) haplotype. Haplotype $\mathrm{H} 2$ is characteristic only 
for humans with European ancestry and is associated with increased expression of exon 3 in grey matter, what might be protective against some NDs [40]. On the contrary, inheritance of the H1/H1 genotype and the haplogroup $\mathrm{H} 1$ is linked to higher probability of certain NDs, such as $\mathrm{AD}$, progressive supranuclear palsy (PSP), cortico-basal degeneration (CBD), idiopathic PD, and argyrophilic grain disease [41]. A greater risk of early dementia development in Down's syndrome is related to a $\mathrm{H} 1 / \mathrm{H} 2$ genotype [42].

The result of alternative splicing of exons 2, 3 and 10 is the presence of six Tau isoforms in human central nervous system (CNS) [43]. It is estimated that the ratio of isoforms containing $3 \mathrm{R}$ (not including exon 10) or 4R (including exon 10) is approximately 50/50 [44]. What is important, the proportion between isoforms $4 \mathrm{R}$ and $3 \mathrm{R}$ is essential for Tau protein function. Isoform $4 \mathrm{R}$ has higher affinity to MTs than $3 R$. Therefore, any change of $3 R$ to $4 R$ ratio may influence on Tau biological activity. It seems that alternative splicing of Tau, resulting in these two isoforms, may be also an essential factor for neurodegeneration [45]. Although both isoforms of Tau, 3R and 4R, may change the distribution of mitochondria within the cell body and reduce their localization to axons, they cause different alterations in retrograde and anterograde transport dynamics. It was demonstrated that $3 \mathrm{R}$ isoform has a slightly stronger effect on axon transport dynamics, what suggests that Tau-induced changes in axonal transport may underlie NDs [46].

It was revealed that the expression of Tau isoforms undergoes a specific 'shift' depending on the stage of development. In fetal period, only the shortest Tau isoform (0N3R) is expressed in the brain, whereas Tau maturation results in the presence of all the six isoforms of this protein in adult CNS [47]. These differences in the expression of Tau isoforms are associated with the formation of synapses, especially in sensory and motor cortices. Attenuated MT binding by fetal isoform 3R in the postnatal period, when compared to the $4 \mathrm{R}$ isoform, is critical for brain development and may be related to higher synaptic plasticity [44,48]. The developmental switch of splicing exon 10 of the Tau gene leads to the incorporation of an additional MT-binding repeat, resulting in increased stabilization of MTs [44]. Additionally, it seems that various populations of neurons may express different isoforms of Tau protein [36]. There are also regional differences in splicing of the mapt gene in the brain. For example, the amount of ON3R tau in humans is lower in the cerebellum, while 4R Tau isoforms are increased in the globus pallidus than in other brain regions $[38,49]$.

Furthermore, Tau molecule contains one or two cysteine residues: Cys322 located in R3 repeat, which is present in all isoforms, and Cys291 in R2 repeat, present only in 4R isoforms [50]. It seems that the balance between these isoforms may be important within the adult brain, and can influence on Tau aggregative properties in vitro [50]. It was shown that oxidation of Cys 322 in the repeat domain of Tau may control its assembly into larger aggregates, called paired helical filaments (PHFs) and NFTs. The redox potential in the neuron is crucial for PHF assembly, independently or in addition to pathological phosphorylation reactions.

\subsection{Post-Translational Modifications of Tau}

As it was mentioned above, each protein directly after translation, must undergo certain post-translational processes to complete its biosynthesis and gain biological activity. In case of Tau, these modifications include phosphorylation, glycosylation, ubiquitination, deamination, oxidation, and others. All post-translational changes may additionally complicate Tau isoforms [36]. Although various physiological processes regulate ability of binding Tau with MTs, the highest importance is ascribed to phosphorylation [45]. It may be confirmed by the fact that hyperphosphorylated Tau (hTau) is the main component of NFTs. The degree of Tau phosphorylation depends on the activity of certain enzymes, such as microtubule affinity regulating kinase (MARK), cycline-dependent kinase 5 (Cdk5), glycogen synthase kinase $3 b$ (GSK3b) and protein kinase 2A [45]. These kinases regulate phosphorylation of Tau in the reaction of esterification of AA present in Tau molecule: serine (S), threonine $(\mathrm{T})$ or tyrosine $(\mathrm{Y})$. 
Activity of Tau is closely related with its phosphorylation. There are up to 85 possible points of phosphorylation in the longest isoform of Tau in CNS (2N4R-Tau), which are located mainly in two flanking regions: the MBD and PRD domains [36,39]. The phosphorylation of these sites is significant for regulation of microtubule polymerization [51-54], controlling of axonal transport [55] and neurotransmitter receptors, such as AMPAR ( $\alpha$-amino-3-hydroxy-5-methyl-4-isoxazolepropionic acid receptor) and NMDAR ( $N$-methyl-D-aspartate receptor) [56,57]. Moreover, overexpression of Tau protein inhibits kinesin-dependent trafficking of vesicles, mitochondria, and endoplasmic reticulum [58]. Phosphorylation of Tau regulates also its interaction with apolipoprotein E [59], Src-family kinases and neural plasma membrane [60-62] as well as interaction with DNA [63], and many others [64,65]. Relationships between Tau phosphorylation and its aggregation depend on the site where it occurs: certain residues are concerned with increased aggregation propensity [66], whereas in other sites it has the opposite effect, thus preventing aggregation [67].

Increased activity of kinases and decreased activity of phosphatases lead to an imbalance between these enzymes, resulting in hyperphosphorylation of Tau protein. Hyperphosphorylated Tau has lower affinity to MTs, induces their misfolding, destabilizes cytoskeleton and impairs axonal transport [36,39]. Interestingly, Tau hyperphosphorylation may also occur in hypothermia [68], starvation [69], chronic stress [70], or anesthesia [71,72].

\subsection{Tau Protein Structure}

Tau may be considered as an example of intrinsically disordered protein (IDP). IDPs are described as proteins without a fixed or ordered three-dimensional structure. They include a wide spectrum of states, from fully unstructured to partially structured molecules, which may comprise random coils, (pre-)molten globules, and large multi-domain proteins, that may be connected by various flexible linking domains [73].

Tau is a highly soluble protein, which is characterized by loose, open structure and natively unfolded conformation with less than $10 \%$ of $\alpha$-helix and $\beta$-sheet regions [74]. However, aforementioned post-translational modifications of Tau, such as phosphorylation, acetylation, or its truncation, lead to alterations in the secondary structure that enable the appearance of $\alpha$-helix or $\beta$-sheet regions in Tau molecule [75]. In solution, Tau molecule spontaneously tends to modify its conformation, favoring a paperclip-like shape [65,76]. In this conformation, the C-terminal end of the protein folds over into the proximity of the MDB repeats, but the $\mathrm{N}$-terminus remains outside the reach of the repeat domain, although both ends of the molecule approach one another [76]. Such intramolecular interaction may prevent the self-aggregation of Tau by masking the regions involved in this process.

The paperclip-like Tau form differs from its extended conformation, which is required for interaction of Tau with MTs. It was demonstrated in the electron microscopic visualization that Tau binds to MTs in a linear alignment, lengthwise to the protofilament edges $[77,78]$. Each repeat of MBD interacts with one tubulin dimer and with its interface to the next tubulin [76-81]. When Tau is detached from MTs, they destabilize. Moreover, the post-translational modifications of Tau may also inhibit forming its paperclip-like structure, resulting in the increased aggregation propensity of this protein [82].

\subsection{Biological Functions of Tau}

The most recognized role of Tau as a scaffold protein, is the regulation of MTs stability, their assembly and spacing [83]. The adult neurons are the cells that not divide, so they need to stabilize their cytoskeleton in order to sustain neuronal processes such as the fast axonal transport through relatively long distances. Thus, normal Tau is an important factor in the MT-dependent axonal transport of signaling molecules and other substances [84]. Interaction of Tau with MTs occurs primarily through the repeated microtubule binding regions. In physiological conditions, Tau remains in a constant, dynamic balance with MTs, binding shortly with them, and after phosphorylation by kinases, a short-term disconnection from MTs occurs, but after the dephosphorylation by phosphatase, Tau is 
again re-attached to MT [85]. What is more, it seems that Tau is an essential factor for axonal elongation and maturation. It was demonstrated that Tau overexpression could induce the formation of neurites even in non-neuronal cells [86], while knockdown of mapt gene may inhibit neurite formation, as it was demonstraded in cultured rodent cerebellar neurons [87].

Whereas the activities of Tau presented above are located presynaptically and relate mainly with axonal part of neurons, the postsynaptic function of Tau remains unclear. It was demonstrated that this protein may be involved in the development of dendrites, as the important factor for neurite and axonal growth, and may contribute to synaptic plasticity [87]. These activities are associated with $\mathrm{N}$-terminal region of Tau, which does not participate in Tau-MTs interactions. It was demonstrated that N-terminal region of Tau plays a role in neurite outgrowth in PC12 cells induced by nerve growth factor (NGF) [88]. PC12 cell line is derived from a pheochromocytoma of the rat adrenal medulla, and serve as cellular model for neurosecretion [89].

The novel roles of Tau, such as neuronal signaling pathways, DNA and RNA protection from oxidative stress, and regulation of synaptic functions, have been revealed. Targeting of Fyn, a tyrosine kinase from src family, in dendritic region of neurons is an example of postsynaptic Tau activity. The proline-rich sequence in the N-terminal half of Tau interacts with Fyn in cultured NIH3T3 cells. These cells function as the standard fibroblast cell line, whereas their co-transfection with Tau and Fyn kinase resulted in alterations in the morphology of NIH3T3 cells [88]. More recent studies demonstrate also a nuclear function of Tau, apart from its axonal and dendritic roles. It was revealed in neuronal cultures, that nuclear Tau may regulate transcriptional activity and maintain the integrity of DNA/RNA under hyperthermia, a known strong inducer of reactive oxygen species (ROS) [90]. This protein plays a protective role in neuronal DNA and RNA integrity in vivo, both under physiological conditions and in oxidative stress [91].

Another, novel role of Tau as a signaling molecule was also described in recent studies. It was revealed that this protein may regulate brain insulin pathway signaling [92]. Insulin signaling is known to control hippocampal plasticity and reference memory [93]. Insulin receptor substrate 1 (IRS-1) plays a key role in transmitting signals from the insulin and insulin-like growth factor-1 (IGF-1) receptors to intracellular pathways PI3K/Akt and Erk MAP kinase pathways. It was demonstrated on Tau knockout mice model that deletion of this protein leads to an impaired hippocampal response to insulin and promoted brain insulin resistance, caused by altered IRS- 1 and PTEN (phosphatase and tensin homologue on chromosome 10) activities [92]. The clinical implications of these findings may be the fact that pathological loss of Tau function favors brain insulin resistance, what is one of the key factors for cognitive and metabolic impairments in $\mathrm{AD}$ patients [93].

\subsection{Aggregation and Deposition of Misfolded Tau Protein}

In addition to paperclip-like structure, Tau protein may also be present as a long, extended molecule, with ability of binding itself into Tau polymers or to other proteins [75]. Reactivity of monomers depends on the presence of thiol groups in cysteine residues. Free thiols in a reactive monomer allow formation of an intra- or intermolecular disulfide linkage [94]. Molecules of Tau with intramolecular disulfide linkage form a nonreactive monomer, whereas presence of one or more free thiols may result in reactive monomers, which are readily able to form an intermolecular disulfide connections and polymerization. Despite a low tendency of native Tau protein to accumulation [80], certain changes of its conformational status may induce the predisposition of this protein to assembly. It is known that Tau aggregation is a multistep process, which probably begins from the hyperphosphorylation of Tau and its detachment from MTs. In the process of aggregation, Tau is relocated to somato-dendritic regions of neurons, where further phosphorylation and structural changes of this protein occur (Table 1). 
Table 1. Major forms of Tau identified.

\begin{tabular}{|c|c|c|}
\hline Species of Tau & Molecular Weight and Size & Toxicity \\
\hline Monomer & $60 \mathrm{kDa}, 352-441 \mathrm{AA}$ & no \\
\hline $\begin{array}{c}\text { Abnormally } \\
\text { phosphorylated non-PHF } \\
\text { Tau (AD P-Tau) }\end{array}$ & 67-70 kDa & $\begin{array}{l}\text { yes } \\
\text { - } \quad \text { detachment of P-Tau from MTs leads } \\
\text { - } \quad \text { missorting of P-Tau: } \\
\text { - } \quad \text { induction of synaptic dysfunction } \\
\text { decrease in the number of } \\
\text { - } \quad \text { loss of the synapses [96] }\end{array}$ \\
\hline Dimer/trimer & $120-180 \mathrm{kDa}$, length $22-25 \mathrm{~nm}$ & $\begin{array}{l}\text { yes, some types } \\
\text { trimeric TauOs: } \\
\text { - } \quad \text { toxic for neurons at nanomolar levels } \\
\text { - } \quad[94] \\
\text { minimal propagation unit }[94]\end{array}$ \\
\hline $\begin{array}{l}\text { Small soluble oligomer } \\
\text { (6-8 molecules) (TauOs) }\end{array}$ & $300-500 \mathrm{kDa}$ & $\begin{array}{l}\text { yes, some types } \\
\text { TauOs containing 6-8 molecules: } \\
\text { - } \quad \text { may develop from soluble dimeric } \\
\text { Tau [97] } \\
\text { - } \quad \text { detected in mice model of tauopathy } \\
\quad[97]\end{array}$ \\
\hline
\end{tabular}

yes, some types

Granular tau oligomers

(36 Tau monomers) (gTauOs)

$1800 \mathrm{kDa}$, diameter 20-50 nm

\begin{tabular}{cc}
\hline Straight filaments (SF) & $>50 \mathrm{~nm}$ length, $10 \mathrm{~nm}$ width \\
\hline $\begin{array}{c}\text { Paired helical filaments } \\
\text { (PHF) }\end{array}$ & $\begin{array}{l}10-20 \mathrm{~nm} \text { width, with } 80 \mathrm{~nm} \\
\text { periodicity, length }>220 \mathrm{~nm}\end{array}$
\end{tabular}
(PHF) periodicity, length $>220 \mathrm{~nm}$
- $\quad$ intermediate step in the formation of PHFs and SFs [98]

- $\quad$ isolated from AD brains [99]

$$
\text { not always }
$$

- Tau hyperphosphorylation may induce its self-assembly into NFTs consisted of PHFs/SFs [100]

$$
\text { probably not toxic }
$$

- highly insoluble and resistant to proteolysis [101]

$$
\text { probably not toxic }
$$

Neurofibrillary tangles

(NFT)

NA
- form of the sequestration of toxic aggregates in neuronal protective response [45]

$$
\text { probably not toxic }
$$

Ghost tangle NA
- $\quad$ remnants of degenerated neurons within which NTFs have been formed [100] 
The result of self-aggregation of highly phosphorylated Tau may be soluble Tau oligomers (TauOs) of many different sizes, including dimers and trimers. It was revealed that any isoform of Tau may form Tau dimers. Two single Tau molecules interact through MBD domain with cysteine residues, forming a covalently linked Tau cysteine-dependent dimers, arranged in an antiparallel manner and linked by disulfide bonds [74]. Moreover, there are two distinct forms of dimeric Tau: reducible and cysteine-dependent dimers or non-reducible, cysteine-independent ones. The latter form has inter-molecular disulfide bridging at the MBD domain. Both dimeric Tau forms have been identified in vitro, as well as in transgenic mice JNPL3 expressing P301L mutation of Tau [97]. As it was mentioned before, 3R Tau isoform contains only one cysteine residue (Cys322 in R3 repeat) and may form its dimers only after oxidation. On the contrary, the 4R Tau isoform, having two cysteine residues (Cys291 in R2 and Cys322 in R3), can form various dimeric forms and an internal disulfide bridge [50]. These dimers are believed to be a crucial intermediate step in the formation of PHFs [50].

Although it is not fully elucidated if Tau dimers are the harmful form of this protein, the toxicity Tau trimers was revealed indeed [94]. It was demonstrated that trimeric forms resulting from two different Tau splice variants were noxious to human neuronal cells at low nanomolar concentrations, whereas monomers and dimers of this protein were not able to exert such effects [94]. Moreover, it was revealed that trimeric TauOs represent the minimal propagation unit, which may be spontaneously internalized by cells and seed further intracellular aggregation of this protein, mediating progression of Tau-related NDs [94]. Both recombinant Tau aggregates and Tau assemblies purified from AD brains with size three or more units were internalized by primary neurons and by HEK293 cells, which stably expresses the repeat domain of 2N4R Tau with two AD-associated mutations (P301L and V337M). Furthermore, it was shown that only 3-unit and larger assemblies from AD brain spontaneously seeded intracellular Tau aggregation in HEK293 cells [102]. These findings point out that the trimeric form is a minimum size of Tau assemblies that allows for spontaneous propagation of Tau aggregation from the outside to the inside of a cell [102].

The molecular size of small soluble Tau oligomers, both recombinant TauOs and isolated from human Tau transgenic mice, ranges between 120-180 kDa [97,103-105]. Moreover, small soluble Tau species, which probably included also Tau fragments, have been isolated from synapses in AD brains [106]. Their molecular weight was reported to correspond approximately dimer and trimer size. Apart from dimers and trimers, also small soluble TauOs containing six to eight Tau molecules and with approximately $300-500 \mathrm{kDa}$ in size, have been described. It was demonstrated that these oligomers may develop from soluble dimeric Tau [97]. In addition, in mice overexpressing human Tau with the P301L mutation and NFTs, small Tau oligomers with a wide range of sizes were also detected [97].

Furthermore, Tau may aggregate into insoluble polymers, such as granular oligomers, straight filaments (SF), PHFs and NFTs. These granular aggregates, with globular shape are composed of approximately 40 monomers of Tau [98]. Their molecular mass reach approximately $1800 \mathrm{kDa}$, while diameter is only $20-50 \mathrm{~nm}$, what indicates that granular TauOs are extremely densely packed [98]. This result in some difficulties in examination, separation and purification of these oligomers, which require certain changes in standard protocols for the fractionation of insoluble proteins. Although granular TauOs are fully insoluble, they are too small to sediment with a standard high-speed centrifuged insoluble fraction and to separate on a standard PAGE resolving gel [100]. It was assessed that sedimentation of granular TauOs requires a 200,000 $\times g$ spin for $2 \mathrm{~h}$ [98].

It is not certain whether granular TauOs develop directly from small soluble oligomers in a linear pathway, or rather from monomers in the different pathway. Insoluble granular TauOs have $\beta$-sheet structure within their molecule and may be composed of partially folded monomeric Tau, what suggests that this type of TauOs may represent the intermediate step in the formation of fibrillar forms of Tau, such as PHFs or SFs [98]. It was shown that development of TauOs may be blocked by capping of cysteine residues with isoproterenol, an adrenergic receptor agonist including 1,2-dihydroxybenzene groups within its molecule [107]. Moreover, it was shown that isoproterenol may reverse certain 
emotional changes associated with the expression of P301L Tau and stimulate activity of neurons in the prelimbic frontal cortex [107].

It was revealed in vitro that Tau protein may aggregate further, forming fibrillar forms of Tau, such as SFs and PHFs [98]. SF strands are approximately $10 \mathrm{~nm}$ wide, therefore twisted fibrils of paired filaments, with approximately $80 \mathrm{~nm}$ periodicity, may exhibit alternating diameters 10 or 20 nm [100]. Recombinant smaller granules of TauOs could grow by binding with molecules of soluble Tau, whereas after long period of incubation, further binding to larger granular TauOs, exceeding a size of $20 \mathrm{~nm}$, may result in the development of Tau fibrils [98]. Interestingly, extended time of incubation to 7 months resulted in the conversion of all Tau monomers and granular TauOs into filaments [98].

The time-dependent increase in Tau phosphorylation at specific sites and its abnormal molecule conformation lead to forming PHFs [43], which are highly insoluble and resistant to proteolysis pathological inclusions [101]. Normal Tau molecules include two phosphates [108], while Tau proteins isolated from AD brains is hyperphosphorylated and contains up to eight phosphates per molecule [109]. Therefore, the aberrations in Tau phosphorylation might be linked to its misfolding and deposition in the diseased brain [110]. Aggregated PHF are referred to as NFTs if they are formed within neuronal cell bodies, whereas aggregates formed in dendrites or axons are called neuropil threads [111].

Further PHFs aggregation leads to the development of NFTs and Pick bodies $[39,45]$. Although the final result of Tau accumulation are NFTs, the precise mechanism of their formation and the sequence in which these events occur is not clearly elucidated. It is neither fully understood whether Tau aggregates represent a primary causative factor in AD or they play a more peripheral role. It was shown that increased ability of Tau for forming PHFs and NFTs is related to disturbed processes of phosphorylation of flanking regions of Tau at certain AA, such as serine 396 and serine 404 [112]. Moreover, Tau phosphorylation at Ser396 and Ser404 by human recombinant Tau protein kinase II inhibited Tau's ability to promote assembly of MTs [113]. It was also demonstrated that the phosphorylation at these sites is one of the earliest events in AD and in Down syndrome [114].

NFTs, first described by Alzheimer in 1907, belong to the pathological hallmarks of AD, although they may also occur in other tauopathies [75]. In AD, NFTs are composed of Tau molecules accumulated to fibrillar aggregates, PHFs and SFs, which may fill the entire neuronal cytoplasm. PHFs differ from SFs the presence heparan and chondroitin sulfates, which are associated to Tau polymers [115]. The process of Tau polymerization into fibrils may be facilitated by various polyanionic cofactors, including glycosaminoglycans like heparin and neuroparin [116], sulphoglycosaminoglycans such as keratins or chondroitin sulfates, fatty acids such as arachadonic acid as well as alkyl sulfate detergents [100]. Moreover, aggregation of Tau and formation of fibrils may be accelerated by metal ions $\left(\mathrm{Pb}^{2+}, \mathrm{Zn}^{2+}\right.$, $\left.\mathrm{Cd}^{2+}, \mathrm{Cu}^{2+}, \mathrm{Mg}^{2+}\right)[117,118]$. Furthermore, it was shown that Tau filaments may spontaneously cluster together into NFTs in vitro [100].

The formation of NFTs may be affected already on the early stages of this process. Although the search for mutations associated with mapt gene, that could be related with AD, have failed, several factors that affect the NFTs development have been identified so far [112]. They include some genetic factors $[119,120]$, exposure to toxins such as nicotine [121] or aluminum $[122,123]$ as well as neurotoxicity of $A \beta$ [124]. Moreover, various pathological processes, such as inflammation [125,126] and oxidative stress [127] may also have an impact on generation of NFTs. Additionally, impaired cholesterol metabolism and atherosclerosis [128-130], dietary deficits [131,132], depression [133,134] and stress [135] may also contribute to formation of NFTs.

The localization of NFTs within AD brain changes depending on the progression of AD, and correlates with the severity of the cognitive decline. Therefore the topographic staging of NFTs may be applied for the pathological diagnosis of $\mathrm{AD} \mathrm{[136].} \mathrm{The} \mathrm{Braak} \mathrm{stages} \mathrm{define} \mathrm{the} \mathrm{degree} \mathrm{of} \mathrm{spatiotemporal}$ NFT's involvement in AD: changes limited to brain transentorhinal region are described as the Braak stages I and II, the involvement of limbic regions such as the hippocampus represents stages III and IV, whereas stages V and VI correspond to extensive neocortical NFTs burden [136]. Moreover, the clinical 
manifestation of $\mathrm{AD}$ and the degree of cognitive impairment is often better reflected by NTF counts than by burden of $A \beta$ plaques in brain [137].

Fibrillar forms of Tau, PHFs and SFs are not only the components of NFTs, but they may form neuropil threads, which are aggregates of hTau in dystrophic neurites largely displacing the cytoskeleton [103]. Neuropil threads are rather early pathological inclusions, which may be also accompanied by Tau dimers and oligomers. These neuropil threads are also the morphological hallmarks of $\mathrm{AD}$ [138]. It has been suggested that the threads may play a role in the cognitive impairment seen in AD [139]. Primarily, NFTs are intraneuronal aggregates of misfolded hTau, but after the death of tangle-bearing neurons, they became the extraneuronal structures called 'ghost' tangles. Ghost tangles are the remnants of degenerated neurons within which NTFs have been formed. They are composed of Tau filaments and fragments, which have undergone substantial proteolysis. Tau molecules within ghost tangles are loosely arranged in large extracellular bundles [100].

\section{Toxic Activity of Tau and TauOs in AD}

\subsection{Tau Protein Toxicity Related to Its Post-Translational Modifications and Missorting}

Although mechanisms of toxic activity of Tau are not fully recognized, it is supposed that the Tau toxicity is related rather not to insoluble Tau aggregates, but to its intermediate forms. It seems that NFTs themselves, despite being composed of toxic Tau, are probably neither necessary nor sufficient for Tau-induced neuronal dysfunction and toxicity. For example, in some animal models of tauopathy, notwithstanding evident neurodegeneration, tangles are not formed at all, or rather later, after the occurrence of cognitive/behavioral impairments and neuronal death [95,140-142]. It was proposed that formation of NFTs might be somehow a failed kind of neuronal protective response against toxic Tau seeding and a form of its toxic aggregates sequestration [45].

Whereas physiological Tau is soluble and non-toxic, under pathological conditions this protein may undergo some modifications and achieve toxic features, even though it may remain soluble. One of the results of post-translational modifications may be the detachment of Tau from microtubules, leading to disassembly of MTs in axons [95]. When disconnected from MTs, Tau diffuse rapidly into other neuronal compartments and, by aberrant sorting within neuronal cell, it may induce synaptic dysfunction. Furthermore, entering of pathological forms of Tau into postsynaptic compartments and dendrites causes a decrease in the number of synaptic vesicles and, finally, loss of the synapses [96]. However, it was revealed in more recent study that missorted Tau in dendrites is not derived from axons but it originates from Tau newly synthesized in the cell body [111].

\subsection{Relationship between Toxic AßOs and TauOs}

Postsynaptic dysfunction of Tau is also associated with a reduction of dendritic spines and local increase in $\mathrm{Ca}^{2+}$. It was observed that this missorting of Tau into dendrites may be caused by $\mathrm{A} \beta \mathrm{O}$ exposure of primary hippocampal neurons [96]. It was also revealed that Tau knockout neurons are resistant to $A \beta O$ toxicity, whereas introduction of Tau could re-sensitize these cells to $A \beta$-induced spine loss and disintegration of MTs [111]. Activity-dependent Tau translocation to excitatory synapse may be disrupted by exposure to $A \beta O s$ [143]. Interestingly, this $A \beta O s$-induced somatodendritic missorting occurs not only with Tau, but also with other axonal proteins such as neurofilaments [142]. Moreover, hyper-phosphorylation of Tau and NFT formation, may be induced by A $\beta O$ s either [144].

It was also demonstrated that $\mathrm{A} \beta \mathrm{O}$ s toxicity may be mediated by the dendritic function of Tau [144]. The NMDAR receptor, which is believed as A $\beta O$ s receptor, is the substrate of Fyn kinase. It was suggested that the tyrosine phosphorylation of Tau by Fyn kinase may also have a role in neuropathogenesis of $\mathrm{AD}$, where upregulation of Fyn is observed [88]. Both in transgenic mice expressing truncated form of Tau $(\triangle \mathrm{Tau})$, which does not include MBD, or in Tau $(-/-)$ mice, the postsynaptic targeting of Fyn was disrupted. The disturbed targeting of this enzyme resulted in alleviation of the excitotoxicity mediated by NMDAR and, finally, the toxicity of AßOs [144]. These 
results demonstrate that both expression of truncated Tau and the deficiency of this protein may prevent memory deficits and improve survival in a mice model of AD. Moreover, the expression of $\Delta$ Tau or deficiency of normal Tau prevented memory deficits in APP23 mice, which are A $\beta$ forming animal model of AD, and improved their survival [144]. Additionally, these deficits were fully rescued in vivo with a peptide uncoupling the Fyn-mediated interaction of NMDAR and another postsynaptic protein PSD-95 (post synaptic density 95). These results suggest that this Tau dendritic activity may result in postsynaptic $A \beta$ toxicity. The associations of Tau with synaptic proteins pave the way to possible direct implications for the pathogenesis and treatment of $A D$ and indicate that dendritic activity of Tau may promote postsynaptic toxicity of $A \beta$. These findings indicate that there is a link in AD pathology between oligomeric forms of various proteins, including amyloid $\beta$ and Tau.

\subsection{Influence of Tau on Synaptic Transmission}

It was shown that inhibition of Tau expression may rescue memory deficits in mice expressing mutated form of Tau $\mathrm{P}_{\mathrm{P} 01 \mathrm{~L}}$, a mouse model of neurodegeneration [145]. After the suppression of transgenic Tau by doxycycline administration, the recovery of memory function and stabilization of neuron numbers were observed. However, suppression of Tau did not induce change in NFTs burden. It seems that tangles themselves are insufficient to cause the cognitive decline or neuronal death in this model of tauopathy [145]. On the contrary, it was suggested that NFTs represent rather a stable, favorable state that probably acts as a sink for remaining Tau P301L $_{\mathrm{L}}$ species. Furthermore, it appears that in AD this degenerating sequence of events, although triggered by Tau overexpression, may branch from a Tau filament formation pathway. Tau may produce aggregates with toxic properties already before forming insoluble fibrils.

It was demonstrated on another animal model of tauopathy that mice expressing highly pro-aggregant $\Delta \mathrm{K} 280$ mutation of this protein can develop synapse loss and various pathological features of Tau, including missorting, phosphorylation and early pretangle formation [146]. Moreover, hippocampal Tau pathology in pro-aggregant mice correlated with impaired synaptic plasticity, loss of LTP in hippocampus and a significant reduction of synaptic proteins and dendritic spines as well as with severe cognitive deficits in learning/memory performance tests. Interestingly, memory deficits and LTP depression recovered, when pro-aggregant Tau was turned off. Moreover, switching-off the pro-aggregant Tau resulted in reduction of its phosphorylation and reversal of Tau missorting, although the insoluble forms of Tau were still present. These findings demonstrate that Tau-induced impairments might be reversible after turn off pro-aggregant Tau [146].

\subsection{Toxic Tau Aggregates}

Growing body of evidence suggests that the soluble species of TauOs, observed already at early stages of AD pathology, seem to be the most deleterious forms of Tau. The prefibrillar TauOs, similarly to $A \beta O$ s, are characterized by the neurotoxicity, infectivity, and ability for amplification, which are the mechanisms that underlie progression of AD, leading to the death of neurons [103,147-149].

It was revealed that pre-fibrillar TauOs may also alter the protective function of normal Tau for nucleic acids in hippocampal neurons in vivo [150]. Pathological Tau cannot enter the nucleus, which may result in DNA damage owing to the loss of the DNA-protective function. It was demonstrated in a mice model of tauopathy, that hyperthermia may selectively induce the oxidative damage and trigger the strand breaks of nucleic acid in hippocampal neurons that display early Tau phosphorylation [150]. It was also revealed that the loss of nuclear Tau protein affects the structure, transcription and repair of neuronal peri-centromeric heterochromatin [151].

Another toxic feature of pathological Tau is the influence on neuronal activity and induction of their hyperexcitability. Besides cognitive impairment, AD has been also referred to as a 'disease of synaptic failure', and may be associated with an increased incidence of unprovoked epileptic-type seizures [152]. Epileptiform activity in AD may be interpreted as a secondary process resulting from advanced stages of neurodegeneration [153]. It was demonstrated that antisense reduction of Tau 
could suppress epileptic seizures in animal models of $\mathrm{AD}$, what indicates that Tau may be involved in the regulating neuronal hyperexcitability [154]. Tau ablation reduced the frequency of seizures in mice model of epilepsy and prevented the high mortality in these animals [155]. Moreover, it prevented biochemical changes in the hippocampus symptomatic for epileptic activity and rescued defects in learning and memory in these mice.

It was shown that normal Tau is essential for long-term depression in the hippocampus [156]. However, by forming toxic aggregates, Tau severely disturbs the neuronal function, especially synaptic transmission. The number of ultra-stable TauOs visualized in brightfield microscopy was estimated to accumulate within trillions of synapses in AD brain cortex, what outnumbers macroscopic Tau aggregates such as NFTs by 10,000-fold [157]. The toxic influence of Tau on synapses may be also related with dissemination of misfolded forms of this protein, especially TauOs. Similarly to $\mathrm{A} \beta \mathrm{O}$ s and prion proteins, $\mathrm{AD}$ brain-derived TauOs may propagate pathology from endogenous Tau, spreading within the living brain and making AD an infectious disease [158]. This distribution may occur when TauOs, released by neurons into the extracellular space, are taken up again by other neurons [157]. An ability of misfolded Tau to transmit across synapses was demonstrated both in AD animal models [159] and human cortical neurons from AD brains [157]. The immunostaining against Alz-50, an antibody which recognizes misfolded Tau in AD-affected brains, was strongly elevated in synaptoneurosomes isolated from AD than in non-demented control brains. This result indicates that Tau may undergo hyperphosphorylation, misfolding, and oligomerization at AD-affected synapses [157]. It was hypothesized that the infectious TauO species might be transmitted through synapses by synaptic vesicular trafficking [160]. Frequent and symmetric deposition of misfolded TauOs within presynaptic and postsynaptic terminals observed in $\mathrm{AD}$ suggests that this vesicular transport of oligomers is possible in either direction of transmission [157]. Another proposed explanation is the uptake of TauOs in neighboring synaptic terminals by accidental endocytosis. Incompletely degraded TauOs, which may remain as debris in the extracellular space, also allows for seeding further Tau misfolding [157].

Since it have become that insoluble aggregates of Tau, such as NFT or PHS might not be toxic, an assumption that granular TauOs perhaps might be the most toxic species of Tau emerged. Granular TauOs are the type of Tau aggregates, which have been isolated from AD brains [99]. These TauO fractions derived from human frontal cortex were detected not only in the samples from AD patients with advanced stages of the disease, characterized by large amount of NFTs, but even in samples from patients with no NFTs in the frontal cortex [98]. Additionally, granular oligomers isolated from the brains of patients with early stages of AD were smaller than those from advanced AD. These results suggest that granular TauOs accumulate before forming of Tau fibrils. Interestingly, it was demonstrated that granular TauOs appear also in non-AD brains, whereas no histologically verified NFTs were observed in these patients [98]. What is important, an increase in granular TauO levels occurs before NFTs form and before manifestation of clinical symptoms of AD, suggesting that elevation in TauOs level may represent a very early sign of brain aging and AD [99]. The summary of physiological functions and possible toxic activities of Tau is presented in Table 2. 
Table 2. Functions of normal Tau and toxic activity of pathological forms of Tau.

\begin{tabular}{|c|c|}
\hline Physiological Functions of Tau & Pathological Activity of Tau \\
\hline $\begin{array}{c}\text { Main distribution in normal healthy } \\
\text { neurons in axons }[82,83] \text { : } \\
\text { Scaffold protein } \\
\text { Stabilization and assembly of MTs } \\
\text { Regulation of axonal transport } \\
\text { Activity through the repeated regions of } \\
\text { MBD }\end{array}$ & $\begin{array}{c}\text { Results of post-translational modifications }[95,96] \text { : } \\
\text { Detachment of tau from microtubules } \\
\text { Microtubule disassembly in axons } \\
\text { Mislocalization in presynaptic terminals } \\
\text { Induction of synaptic dysfunction } \\
\text { Reduction in the number of synaptic vesicles in presynaptic } \\
\text { terminals } \\
\text { Synapse loss }\end{array}$ \\
\hline $\begin{array}{c}\text { Dendritic function associated with } \\
\text { N-terminal region of Tau [87]: } \\
\text { Detected in dendrites in small amounts } \\
\text { Involved in the development of } \\
\text { dendrites } \\
\text { Important factor for neurite and axonal } \\
\text { growth } \\
\text { Contribution to synaptic plasticity } \\
\text { Neurite outgrowth }\end{array}$ & $\begin{array}{c}\text { Missorting of pathological Tau into dendrites and postsynaptic } \\
\text { compartments [96,157]: } \\
\text { Induction of postsynaptic dysfunction mediated by A } \beta \text { oligomers } \\
\text { Synapse loss } \\
\text { Dendritic pathological tau [144]: } \\
\text { Transport of FYN kinase to the postsynaptic sites. } \\
\text { Reduction of dendritic spines and local increase in } \mathrm{Ca}^{2+} \text {. } \\
\text { Enhancement of A } \beta \text { toxicity }\end{array}$ \\
\hline $\begin{array}{c}\text { Nuclear function }[89,90]: \\
\text { DNA and RNA protection from } \\
\text { oxidative stress } \\
\text { Regulation of transcriptional activity } \\
\text { Maintaining the integrity of genomic } \\
\text { DNA and RNA in hyperthermia }\end{array}$ & $\begin{array}{l}\text { Loss of possibility to enter the nucleus by pathologic Tau [93]: } \\
\text { Loss of the DNA-protective function of tau } \\
\text { DNA damage }\end{array}$ \\
\hline \multirow[t]{3}{*}{$\begin{array}{l}\text { Neuronal signaling pathways-PRD } \\
\text { domain [91]: } \\
\text { Regulation of brain insulin pathway } \\
\text { signaling }\end{array}$} & $\begin{array}{c}\text { Signaling molecule in the postsynaptic compartment [144,146]: } \\
\text { Influence on neuronal activity } \\
\text { Disturbed synaptic transmission } \\
\text { Loss of LTP in hippocampus } \\
\text { Impaired synaptic plasticity } \\
\text { Significant reduction of synaptic proteins and dendritic spines } \\
\text { Strengthening the excitotoxicity of A } \beta \text { Os by excitatory } \\
\text { neurotransmitters NMDA and PSD95 } \\
\text { Induction of neuronal hyperexcitability } \\
\text { Cognitive deficits in learning/memory performance tests in mice } \\
\text { model of tauopathy }\end{array}$ \\
\hline & $\begin{array}{c}\text { Formation of aggregates }[99,102,112]: \\
\text { Disturbed neuronal function } \\
\text { Release of Tau aggregates into extracellular space } \\
\text { Uptake of Tau aggregates by other neurons } \\
\text { Spread of Tau pathology }\end{array}$ \\
\hline & $\begin{array}{l}\text { Tau knockout [93]: } \\
\text { Impaired hippocampal response to insulin and promotion of brain } \\
\text { insulin resistance }\end{array}$ \\
\hline
\end{tabular}

\section{Diagnostic Possibilities of TauOs Determination}

There is a lack of single laboratory biomarker for the diagnosis of AD. The recommendations for diagnosing AD comprise the evaluation of Mini Mental State Examination test (MMSE), as well as neuroimaging techniques, such as magnetic resonance imaging (MRI) and positron emission tomography (PET) scans of the brain. The concentrations of A $\beta 42$ and Tau proteins (total Tau and its phosphorylated form $\mathrm{Tau}_{181}$ ) in the cerebrospinal fluid (CSF) are considered the major CSF biomarkers in $\mathrm{AD}$ pathogenesis, and they have been included as research criteria for the diagnosis of $\mathrm{AD}$ since 2007 [161]. However, it should be highlighted that the current clinical criteria of AD [162] and MCI [163] do not include the use of laboratory biomarkers in everyday routine. Apart from these core CSF 
biomarkers, neurofilament light protein (NFL) and plasma total Tau have also been reported to be associated with AD [164].

Taking into consideration the role of TauOs in pathogenesis of $\mathrm{AD}$, it could be helpful if the detection and measurement of their CSF and/or blood levels was also possible. Since accumulation of prefibrillar pathological forms of Tau, especially TauOs, is rather an early event in the progression of $\mathrm{AD}$ pathology, it is reasonable to develop laboratory tests for their measurement, probably with addition to assays for $\mathrm{A} \beta \mathrm{O}$ s as the biomarkers which could facilitate pre-symptomatic diagnosis and staging of $\mathrm{AD}$.

Therefore, there is a need to generate the reagents, especially specific antibodies, which could selectively recognize oligomeric forms of Tau. There were isolated three different single chain antibody fragments (scFvs): F9T, D11C and H2A, which may recognize naturally occurring Tau aggregates either produced by cultured neurons or naturally present in brain tissue from an AD mouse model or human AD brain samples [165]. It was demonstrated that these scFvs specifically bind toxic TauOs, but not monomeric or fibrillar tau. Moreover, they could detect the presence of oligomeric Tau in mouse brain samples from mice model of AD earlier than NFTs may be typically identified. In addition, these antibody fragments could also differentiate between AD and cognitively normal post-mortem human brains, what demonstrates the possibility of developing the biomarkers for early detection and progression of $\mathrm{AD}$ [165].

More recent studies demonstrated the presence of TauOs in samples of CSF collected from patients with various degrees of cognitive impairment, which was confirmed in Western blot analysis with anti-TauOs antibodies, T22 (rabbit polyclonal), and TOMA (mouse monoclonal) [166]. Concentrations of TauOs were elevated in AD patients compared to age-matched controls. Similarly, the ratio of oligomeric to total Tau (TauO/t-Tau) was increased in AD patients, with the higher values in moderate to severe $\mathrm{AD}$ group than in mild $\mathrm{AD}$ and non-demented controls [166]. These results suggest that the measurements of TauOs in CSF could be added to the panel of CSF biomarkers for the diagnosis of AD.

Although Tau is an intracellular protein with certain functions inside the cell, it may be either secreted actively into the extracellular space, what could be a physiological response of neurons to increased intracellular amounts of this protein during the progression of AD. Furthermore, the functions of the blood-brain and blood-CSF barriers may be disturbed in $A D$, where $A \beta O$ s could damage their integrity by activation of matrix metalloproteinases (MMPs) [167]. Thus, in AD A $\beta O s$ and MMPs may additionally contribute to the passage of Tau and other proteins from CSF to the blood [167].

The diagnostic utility of TauOs as early plasma biomarker of AD was assessed using D11C, another scFvs that selectively binds oligomeric Tau [168]. Longitudinal analysis of plasma samples demonstrated that levels of D11C-reactive TauOs were significantly higher in AD patients with dementia than in non-demented controls and these levels increased with the progression of AD [168]. Concentrations of TauOs in the sera of AD patients and aged controls were also measured using anti-oligomeric antibody T22 [169]. Although TauOs were present in the serum of AD patients, they could be detected also in non-demented subjects and correlated positively with age. These findings suggest that clearance of extracellular Tau proteins might take place in the periphery, outside the CNS. What is important, in patients with mild cognitive impairment (MCI) and MCI due to AD (MCI-AD) serum levels of TauOs were lower than in control group. It seems that the decreased levels of TauOs in MCI patients, could be the result of impaired clearance of Tau from brain to blood and consequent extracellular accumulation of Tau aggregates.

\section{Conclusions}

In the current study we have examined literature on the role of various species of Tau in synaptic dysfunction, memory loss, as well as in seeding and spreading of AD. Although the causative role of $\mathrm{A} \beta$ cascade in the development of $\mathrm{AD}$ has been the main explanation of pathological processes of this devastating disease for last 25 years, it became evident, that this hypothesis is not sufficient for 
elucidation all its aspects. Amyloid $\beta$ theory has been recently reconsidered by pointing attention to oligomeric forms of $A \beta$, which probably are the toxic species of amyloid. However, this complemented hypothesis also does not explain all pathological features of AD. Additionally, since A $\beta$ plaques and NFTs co-occur in AD with different topological and temporal patterns, the scientific attention has shifted to another protein with possible influence on the development of AD, Tau protein, which is the main component of these aggregates.

It was demonstrated that in $\mathrm{AD}$ the pathological role may be assigned to Tau, especially its aggregated forms. It was shown that NFTs better than $A \beta$ plaques correspond with the duration and severity of $\mathrm{AD}$, predicting cognitive status in this disease. Moreover, it was suggested that rather soluble oligomers of Tau than insoluble aggregates of this protein may be responsible for harmful effects in AD. It is difficult to precisely determine the most toxic form of Tau, which may be present in multiple, various soluble species, possessing very different properties, as well as macroscopic insoluble fibrils. Besides the six splice variants of Tau $(0 \mathrm{~N}, 1 \mathrm{~N}, 2 \mathrm{~N}$ multiplied by $3 \mathrm{R}$ and $4 \mathrm{R})$, there are three major conformations described (paperclip-like, nonreactive with internal disulfide bridge and reactive with free thiol groups). This abundance of isoforms is complicated by the array of various phosphorylation and other post-translational combinations. Furthermore, two conformations of dimeric Tau depending on cysteine, as well as Tau trimers, and various sizes and phosphorylation states of TauOs were described. All these species of Tau may have importance in the development of AD, but it seems that the soluble oligomers such as granular TauOs are the most detrimental form of Tau. On the contrary, formation of insoluble NFTs was suggested rather as a protective response of damaged neurons than as a necessary precursor of the neuronal death in AD.

There is an urgent need to develop simple, reliable and sensitive biomarkers of AD that can both diagnose $\mathrm{AD}$ at an early enough stage, when therapies can be effective, and be used for screening the treatment of AD. Ideally, these biomarkers would be blood-based, since collecting blood samples is an easier and less invasive intervention than lumbar puncture. Is seems reasonable that TauOs could be promising candidates for such biomarkers of $\mathrm{AD}$, especially TauOs in plasma or serum of $\mathrm{AD}$ patients. However, additional studies are needed before implementation of the analysis of TauOs as a diagnostically useful method for the routine clinical assessment of AD patients. The development of validated biomarker tests by measuring TauOs in the blood would require performing the series of robust, well standardized assays with appropriate high sensitivity. Before implementation, these assays should also be confirmed on large cohorts of patients in critical multi-centre comparison.

Funding: This research was funded by Medical University of Bialystok, grant number "SUB/1/DN/19/003/1198" and "The APC was funded by Medical University of Bialystok".

Conflicts of Interest: B.M. has received consultation and/or lecture honoraria from Abbott, Roche, Cormay and Biameditek.

\section{Abbreviations}

AA

NFTs

NDs

BSE

CJD

$\mathrm{AD}$

HD

PD

$\mathrm{A} \beta$

$\mathrm{A} \beta \mathrm{Os}$

LTP

LTD amino acids

neurofibrillary tangles

neurodegenerative diseases

bovine spongiform encephalopathy

Creutzfeldt-Jakob disease

Alzheimer's disease

Huntington's disease

Parkinson's disease

amyloid beta

oligomers of amyloid $\beta$ peptide

long-term potentiation

enhanced long-term synaptic depression 


\begin{tabular}{|c|c|}
\hline LMW & low molecular weight \\
\hline HMW & high molecular weight \\
\hline MT & Microtubule \\
\hline MAP & microtubule-associated proteins \\
\hline PRD & proline-rich domain \\
\hline MBD & microtubule binding domain \\
\hline PNS & peripheral nervous system \\
\hline PSP & progressive supranuclear palsy \\
\hline CBD & cortico-basal degeneration \\
\hline CNS & central nervous system \\
\hline PHFs & paired helical filaments \\
\hline hTau & hyperphosphorylated Tau \\
\hline MARK & microtubule affinity regulating kinase \\
\hline Cdk5 & cycline-dependent kinase 5 \\
\hline GSK3b & glycogen synthase kinase $3 b$ \\
\hline NMDAR & $N$-methyl-D-aspartate receptor \\
\hline AMPAR & $\alpha$-amino-3-hydroxy-5-methyl-4-isoxazolepropionic acid receptor \\
\hline IDP & intrinsically disordered protein \\
\hline NGF & nerve growth factor \\
\hline ROS & reactive oxygen species \\
\hline IGF-1 & insulin-like growth factor-1 \\
\hline IRS-1 & Insulin receptor substrate 1 \\
\hline PTEN & phosphatase and tensin homologue on chromosome 10 \\
\hline TauOs & oligomers of Tau protein \\
\hline SF & straight filaments \\
\hline PSD-95 & post synaptic density 95 protein \\
\hline MMSE & Mini Mental State Examination test \\
\hline MRI & magnetic resonance imaging \\
\hline PET & positron emission tomography \\
\hline CSF & cerebrospinal fluid \\
\hline NFL & neurofilament light protein \\
\hline scFvs & single chain antibody fragments \\
\hline MMPs & matrix metalloproteinases \\
\hline $\mathrm{MCI}$ & mild cognitive impairment \\
\hline TTR & transthyretin \\
\hline ATTRwt & wild-type amyloidogenic transthyretin \\
\hline ATTRv & variant amyloidogenic transthyretin \\
\hline TTR-FAP & transthyretin-related familial amyloid polyneuropathy \\
\hline
\end{tabular}

\section{References}

1. Alberts, B.; Johnson, A.; Lewis, J.; Raff, M.; Roberts, K.; Walter, P. Protein Function. In Molecular Biology of the Cell, 4th ed.; Garland Science: New York, NY, USA, 2002.

2. Anfinsen, D.C.B. The Formation and Stabilization of Protein Structure. Biochem. J. 1972, 128, 737-749. [CrossRef] [PubMed]

3. Taylor, J.P.; Hardy, J.; Fischbeck, K.H. Toxic proteins in neurodegenerative disease. Science 2002, 296, 1991-1995. [CrossRef] [PubMed]

4. Moreno-Gonzalez, I.; Soto, C. Misfolded protein aggregates: Mechanisms, structures and potential for disease transmission. Semin. Cell Dev. Biol. 2011, 22, 482-487. [CrossRef] [PubMed]

5. Ingram, V.M. Gene mutations in human haemoglobin: The chemical difference between normal and sickle cell haemoglobin. Nature 1957, 180, 326-328. [CrossRef] [PubMed]

6. Gibson, J.S.; Ellory, J.C. Membrane transport in sickle cell disease. Blood Cells Mol. Dis. 2002, $28,303-314$. [CrossRef] 
7. Chamcheu, J.C.; Siddiqui, I.A.; Syed, D.N.; Adhami, V.M.; Liovic, M.; Mukhtar, H. Keratin gene mutations in disorders of human skin and its appendages. Arch. Biochem. Biophys. 2011, 508, 123-137. [CrossRef] [PubMed]

8. Koike, H.; Katsuno, M. Ultrastructure in Transthyretin Amyloidosis: From Pathophysiology to Therapeutic Insights. Biomedicines 2019, 7, 11. [CrossRef]

9. Kumar, V.; Sami, N.; Kashav, T.; Islam, A.; Ahmad, F.; Hassan, M.I. Protein aggregation and neurodegenerative diseases: From theory to therapy. Eur. J. Med. Chem. 2016, 124, 1105-1120. [CrossRef]

10. Dovidchenko, N.V.; Leonova, E.I.; Galzitskaya, O.V. Mechanisms of amyloid fibril formation. Biochemistry 2014, 79, 1515-1527. [CrossRef]

11. Toyama, B.H.; Weissman, J.S. Amyloid structure: Conformational diversity and consequences. Ann. Rev. Biochem. 2011, 80, 557-585. [CrossRef]

12. Prusiner, S.B. Biology and genetics of prions causing neurodegeneration. Annu. Rev. Genet. 2013, 47, 601-623. [CrossRef] [PubMed]

13. Baumann, F.; Tolnay, M.; Brabeck, C.; Pahnke, J.; Kloz, U.; Niemann, H.H.; Heikenwalder, M.; Rülicke, T.; Bürkle, A.; Aguzzi, A. Lethal recessive myelin toxicity of prion protein lacking its central domain. Embo J. 2007, 26, 538547. [CrossRef] [PubMed]

14. Soto, C.; Estrada, L.; Castilla, J. Amyloids, prions and the inherent infectious nature of misfolded protein aggregates. Trends Biochem. Sci. 2007, 31, 150-155. [CrossRef] [PubMed]

15. Dobson, C.M. The structural basis of protein folding and its links with human disease. Philos. Trans. $R$ Soc. Lond. B Biol. Sci. 2001, 356, 133-145. [CrossRef] [PubMed]

16. Knowles, T.P.; Vendruscolo, M.; Dobson, C.M. The amyloid state and its association with protein misfolding diseases. Nat. Rev. Mol. Cell Biol. 2014, 15, 384-396. [CrossRef]

17. MacLea, K.S. What makes a prion: Infectious proteins from animals to yeast. Int. Rev. Cell Mol. Biol. 2017, 329, 227-276. [CrossRef] [PubMed]

18. Alzheimer, A. Uber eine eigenartige Erkrankung der Hirnrinde. Allgemeine Zeitschrift fur Psychiatrie und psychisch-gerichtliche Medizin 1907, 64, 146-148.

19. Terry, R.; Hansen, L.; Masliah, E. Structural basis of the cognitive alterations in Alzheimer disease. In Alzheimer Disease; Terry, R., Katzman, R., Eds.; Raven: New York, NY, USA, 1994; pp. 179-196.

20. Mroczko, B.; Groblewska, M.; Litman-Zawadzka, A.; Kornhuber, J.; Lewczuk, P. Amyloid $\beta$ oligomers (AßOs) in Alzheimer's disease. J. Neural Transm. 2018, 125, 177-191. [CrossRef] [PubMed]

21. Lansbury, P.T. Evolution of amyloid: What normal protein folding may tell us about fibrillogenesis and disease. Proc. Natl. Acad. Sci. USA 1999, 96, 3342-3344. [CrossRef]

22. Kayed, R.; Lasagna-Reeves, C.A. Molecular mechanisms of amyloid oligomers toxicity. J. Alzheimers Dis. 2013, 33, S67-S78. [CrossRef]

23. Scheff, S.W.; Price, D.A.; Schmitt, F.A.; DeKosky, S.T.; Mufson, E.J. Synaptic alterations in CA1 in mild Alzheimer disease and mild cognitive impairment. Neurology 2007, 68, 1501-1508. [CrossRef] [PubMed]

24. Shankar, G.M.; Li, S.; Mehta, T.H.; Garcia-Munoz, A.; Shepardson, N.E.; Smith, I.; Brett, F.M.; Farrell, M.A.; Rowan, M.J.; Lemere, C.A.; et al. Amyloid-beta protein dimers isolated directly from Alzheimer's brains impair synaptic plasticity and memory. Nat. Med. 2008, 14, 837-842. [CrossRef] [PubMed]

25. Condello, C.; Stöehr, J. A $\beta$ propagation and strains: Implications for the phenotypic diversity in Alzheimer's disease. Neurobiol. Dis. 2018, 109, 191-200. [CrossRef] [PubMed]

26. Mroczko, B.; Groblewska, M.; Litman-Zawadzka, A.; Kornhuber, J.; Lewczuk, P. Cellular Receptors of Amyloid $\beta$ Oligomers (A $\beta O s$ ) in Alzheimer's Disease. Int. J. Mol. Sci. 2018, 19, 1884. [CrossRef]

27. Chételat, G. Alzheimer disease: A $\beta$-independent processes-rethinking preclinical AD. Nat. Rev. Neurol. 2013, 9, 123-124. [CrossRef] [PubMed]

28. Chételat, G. Reply: The amyloid cascade is not the only pathway to AD. Nat. Rev. Neurol. 2013, 9, 356. [CrossRef] [PubMed]

29. Vishnu, V.Y. Can tauopathy shake the amyloid cascade hypothesis? Nat. Rev. Neurol. 2013, 9, 356. [CrossRef]

30. Mudher, A.; Lovestone, S. Alzheimer's disease-do tauists and baptists finally shake hands? Trends Neurosci. 2002, 25, 22-26. [CrossRef]

31. Moher, D.; Liberati, A.; Tetzlaff, J.; Altman, D.G.; The PRISMA Group. Preferred Reporting Items for Systematic Reviews and Meta-Analyses: The PRISMA Statement. PLoS Med 2009, 6, e1000097. [CrossRef] 
32. Trojanowski, J.Q.; Schuck, T.; Schmidt, M.L.; Lee, V.M. Distribution of tau proteins in the normal human central and peripheral nervous system. J. Histochem. Cytochem. 1989, 37, 209-215. [CrossRef]

33. Avila, J.; de Barreda, E.G.; Pallas-Bazarra, N.; Hernandez, F. Tau and neuron aging. Aging Dis. 2013, 4, $23-28$. [PubMed]

34. Guo, T.; Noble, W.; Hanger, D.P. Roles of tau protein in health and disease. Acta. Neuropathol. 2017, 133, 665-704. [CrossRef] [PubMed]

35. León-Espinosa, G.; García, E.; García-Escudero, V.; Hernández, F.; Defelipe, J.; Avila, J. Changes in Tau phosphorylation in hibernating rodents. J. Neurosci. Res. 2013, 91, 954-962. [CrossRef] [PubMed]

36. Hernández, F.; Avila, J. Tauopathies. Cell Mol. Life Sci. 2007, 64, 2219-2233. [CrossRef] [PubMed]

37. Goedert, M.; Spillantini, M.G.; Crowther, R.A. Cloning of a big tau microtubule-associated protein characteristic of the peripheral nervous system. Proc. Natl. Acad. Sci. USA 1992, 89, 1983-1987. [CrossRef] [PubMed]

38. Boutajangout, A.; Authelet, M.; Blanchard, V.; Touchet, N.; Tremp, G.; Pradier, L.; Brion, J.P. Characterisation of cytoskeletal abnormalities in mice transgenic for wild-type human tau and familial Alzheimer's disease mutants of APP and presenilin-1. Neurobiol. Dis. 2004, 15, 47-60. [CrossRef] [PubMed]

39. Martin, L.; Latypova, X.; Terro, F. Post-translational modifications of tau protein: Implications for Alzheimer's disease. Neurochem. Int. 2011, 58, 458-471. [CrossRef] [PubMed]

40. Caffrey, T.M.; Joachim, C.; Wade-Martins, R. Haplotype-specific expression of the N-terminal exons 2 and 3 at the human MAPT locus. Neurobiol. Aging 2008, 29, 1923-1929. [CrossRef] [PubMed]

41. Arendt, T.; Stieler, J.T.; Holzer, M. Tau and tauopathies. Brain Res. Bull. 2016, 126, 238-292. [CrossRef]

42. Jones, E.L.; Margallo-Lana, M.; Prasher, V.P.; Ballard, C.G. The extended tau haplotype and the age of onset of dementia in Down syndrome. Dement. Geriatr. Cogn. Disord. 2008, 26, 199-202. [CrossRef]

43. Wang, J.Z.; Liu, F. Microtubule-associated protein tau in development, degeneration and protection of neurons. Prog. Neurobiol. 2008, 85, 148-175. [CrossRef] [PubMed]

44. Goedert, M.; Jakes, R. Expression of separate isoforms of human tau protein: Correlation with the tau pattern in brain and effects on tubulin polymerization. Embo J. 1990, 9, 4225-4230. [CrossRef] [PubMed]

45. Spires-Jones, T.L.; Stoothoff, W.H.; de Calignon, A.; Jones, P.B.; Hyman, B.T. Tau pathophysiology in neurodegeneration: A tangled issue. Trends Neurosci. 2009, 32, 150-159. [CrossRef] [PubMed]

46. Stoothoff, W.; Jones, P.B.; Spires-Jones, T.L.; Joyner, D.; Chhabra, E.; Bercury, K.; Fan, Z.; Xie, H.; Bacskai, B.; Edd, J.; et al. Differential effect of three-repeat and four-repeat tau on mitochondrial axonal transport. J. Neurochem. 2009, 111, 417-427. [CrossRef] [PubMed]

47. Goedert, M.; Spillantini, M.G.; Jakes, R.; Rutherford, D.; Crowther, R.A. Multiple isoforms of human microtubule-associated protein tau: Sequences and localization in neurofibrillary tangles of Alzheimer's disease. Neuron 1989, 3, 519-526. [CrossRef]

48. Knowles, R.; LeClerc, N.; Kosik, K.S. Organization of actin and microtubules during process formation in tau-expressing Sf9 cells. Cell Motil. Cytoskeleton. 1994, 28, 256-264. [CrossRef] [PubMed]

49. McMillan, P.; Korvatska, E.; Poorkaj, P.; Evstafjeva, Z.; Robinson, L.; Greenup, L.; Leverenz, J.; Schellenberg, G.D.; D'Souza, I. Tau isoform regulation is region- and cell-specific in mouse brain. J. Comp. Neurol. 2008, 511, 788-803. [CrossRef] [PubMed]

50. Schweers, O.; Mandelkow, E.M.; Biernat, J.; Mandelkow, E. Oxidation of cysteine-322 in the repeat domain of microtubule-associated protein tau controls the in vitro assembly of paired helical filaments. Proc. Natl. Acad. Sci. USA 1995, 92, 8463-8467. [CrossRef]

51. Lee, G.; Neve, R.L.; Kosik, K.S. The microtubule binding domain of tau protein. Neuron 1989, 2, $1615-1624$. [CrossRef]

52. Butner, K.A.; Kirschner, M.W. Tau protein binds to microtubules through a flexible array of distributed weak sites. J. Cell Biol. 1991, 115, 717-730. [CrossRef]

53. Goode, B.L.; Denis, P.E.; Panda, D.; Radeke, M.J.; Miller, H.P.; Wilson, L.; Feinstein, S.C. Functional interactions between the proline-rich and repeat regions of tau enhance microtubule binding and assembly. Mol. Biol. Cell 1997, 8, 353-365. [CrossRef] [PubMed]

54. Mukrasch, M.D.; Biernat, J.; von Bergen, M.; Griesinger, C.; Mandelkow, E.; Zweckstetter, M. Sites of tau important for aggregation populate beta-structure and bind to microtubules and polyanions. J. Biol. Chem. 2005, 280, 24978-24986. [CrossRef] [PubMed] 
55. Xia, D.; Li, C.; Gotz, J. Pseudophosphorylation of Tau at distinct epitopes or the presence of the P301L mutation targets the microtubule-associated protein Tau to dendritic spines. Biochim. Biophys. Acta 2015, 1852, 913-924. [CrossRef] [PubMed]

56. Cardona-Gomez, G.P.; Arango-Davila, C.; Gallego-Gomez, J.C.; Barrera-Ocampo, A.; Pimienta, H.; Garcia-Segura, L.M. Estrogen dissociates Tau and alpha-amino-3-hydroxy-5-methylisoxazole-4-propionic acid receptor subunit in postischemic hippocampus. Neuroreport 2006, 17, 1337-1341. [CrossRef] [PubMed]

57. Miyamoto, T.; Stein, L.; Thomas, R.; Djukic, B.; Taneja, P.; Knox, J.; Vossel, K.; Mucke, L. Phosphorylation of tau at $\mathrm{Y} 18$, but not tau-fyn binding, is required for tau to modulate NMDA receptor-dependent excitotoxicity in primary neuronal culture. Mol. Neurodegener. 2017, 12, 41. [CrossRef] [PubMed]

58. Ebneth, A.; Godemann, R.; Stamer, K.; Illenberger, S.; Trinczek, B.; Mandelkow, E.; Mandelkow, E. Overexpression of tau protein inhibits kinesin-dependent trafficking of vesicles, mitochondria, and endoplasmic reticulum: Implications for Alzheimer's disease. J. Cell Biol. 1998, 143, 777-794. [CrossRef] [PubMed]

59. Strittmatter, W.J.; Saunders, A.M.; Goedert, M.; Weisgraber, K.H.; Dong, L.M.; Jakes, R.; Huang, D.Y.; Pericak-Vance, M.; Schmechel, D.; Roses, A.D. Isoform-specific interactions of apolipoprotein E with microtubule-associated protein tau: Implications for Alzheimer disease. Proc. Natl. Acad. Sci. USA 1994, 91, 11183-11186. [CrossRef]

60. Reynolds, C.H.; Garwood, C.J.; Wray, S.; Price, C.; Kellie, S.; Perera, T.; Zvelebil, M.; Yang, A.; Sheppard, P.W.; Varndell, I.M.; et al. Phosphorylation regulates tau interactions with Src homology 3 domains of phosphatidylinositol 3-kinase, phospholipase Cgamma1, Grb2, and Src family kinases. J. Biol. Chem. 2008, 283, 18177-18186. [CrossRef]

61. Bhaskar, K.; Yen, S.-H.; Lee, G. Disease-related modifications in tau affect the interaction between Fyn and Tau. J. Biol. Chem. 2005, 280, 35119-35125. [CrossRef]

62. Lee, G. Tau and src family tyrosine kinases. Biochim. Biophys. Acta 2005, 1739, 323-330. [CrossRef]

63. Qi, H.; Cantrelle, F.-X.; Benhelli-Mokrani, H.; Smet-Nocca, C.; Buée, L.; Lippens, G.; Bonnefoy, E.; Galas, M.-C.; Landrieu, I. Nuclear magnetic resonance spectroscopy characterization of interaction of tau with DNA and its regulation by phosphorylation. Biochemistry 2015, 54, 1525-1533. [CrossRef] [PubMed]

64. Morris, M.; Maeda, S.; Vossel, K.; Mucke, L. The many faces of tau. Neuron 2011, 70, 410-426. [CrossRef] [PubMed]

65. Wang, Y.; Mandelkow, E. Tau in physiology and pathology. Nat. Rev. Neurosci. 2015, 17, 22-35. [CrossRef]

66. Vega, I.E. Increase in tau tyrosine phosphorylation correlates with the formation of tau aggregates. Brain Res. Mol. Brain Res. 2005, 138, 135-144. [CrossRef] [PubMed]

67. Schneider, A.; Biernat, J.; von Bergen, M.; Mandelkow, E.; Mandelkow, E.M. Phosphorylation that detaches tau protein from microtubules (Ser262, Ser214) also protects it against aggregation into Alzheimer paired helical filaments. Biochemistry 1999, 38, 3549-3558. [CrossRef] [PubMed]

68. Planel, E. Alterations in glucose metabolism induce hypothermia leading to tau hyperphosphorylation through differential inhibition of kinase and phosphatase activities: Implications for Alzheimer's disease. J. Neurosci. 2004, 24, 2401-2411. [CrossRef]

69. Yanagisawa, M.; Planel, E.; Ishiguro, K.; Fujita, S.C. Starvation induces tau hyperphosphorylation in mouse brain: Implications for Alzheimer's disease. FEBS Lett. 1999, 461, 329-333. [CrossRef]

70. Sotiropoulos, I.; Catania, C.; Pinto, L.G.; Silva, R.; Pollerberg, G.E.; Takashima, A.; Sousa, N.; Almeida, O.F.X. Stress acts cumulatively to precipitate Alzheimer's disease-like tau pathology and cognitive deficits. J. Neurosci. 2011, 31, 7840-7847. [CrossRef]

71. Le Freche, H.; Brouillette, J.; Fernandez-Gomez, F.-J.; Patin, P.; Caillierez, R.; Zommer, N.; Sergeant, N.; Buée-Scherrer, V.; Lebuffe, G.; Blum, D.; et al. Tau phosphorylation and sevoflurane anesthesia. Anesthesiology 2012, 116, 779-787. [CrossRef]

72. Whittington, R.A.; Bretteville, A.; Dickler, M.F.; Planel, E. Anesthesia and tau pathology. Prog. Neuropsychopharmacol. Biol. Psychiatry 2013, 47, 147-155. [CrossRef]

73. Andreeva, A.; Howorth, D.; Chothia, C.; Kulesha, E.; Murzin, A.G. SCOP2 prototype: A new approach to protein structure mining. Nucleic Acids Res. 2014, 42, D310-D314. [CrossRef] [PubMed]

74. Friedhoff, P.; von Bergen, M.; Mandelkow, E.M.; Mandelkow, E. Structure of tau protein and assembly into paired helical filaments. Biochim. Biophys. Acta 2000, 1502, 122-132. [CrossRef] 
75. Avila, J.; Jiménez, J.S.; Sayas, C.L.; Bolós, M.; Zabala, J.C.; Rivas, G.; Hernández, F. Tau Structures. Front. Aging Neurosci. 2016, 8, 262. [CrossRef] [PubMed]

76. Jeganathan, S.; von Bergen, M.; Brutlach, H.; Steinhoff, H.-J.; Mandelkow, E. Global hairpin folding of tau in solution. Biochemistry 2006, 45, 2283-2293. [CrossRef] [PubMed]

77. Al-Bassam, J.; Ozer, R.S.; Safer, D.; Halpain, S.; Milligan, R.A. MAP2 and tau bind longitudinally along the outer ridges of microtubule protofilaments. J. Cell Biol. 2002, 157, 1187-1196. [CrossRef]

78. Goux, W.J.; Kopplin, L.; Nguyen, A.D.; Leak, K.; Rutkofsky, M.; Shanmuganandam, V.D.; Sharma, D.; Inouye, H.; Kirschner, D.A. The formation of straight and twisted filaments from short tau peptides. J. Biol. Chem. 2004, 279, 26868-26875. [CrossRef] [PubMed]

79. Zabik, N.L.; Imhof, M.M.; Martic-Milne, S. Structural evaluations of tau protein conformation: Methodologies and approaches. Biochem. Cell Biol. 2017, 95, 338-349. [CrossRef]

80. Mukrasch, M.D.; Bibow, S.; Korukottu, J.; Jeganathan, S.; Biernat, J.; Griesinger, C.; Mandelkow, E.; Zweckstetter, M. Structural polymorphism of 441-residue tau at single residue resolution. PLoS Biol. 2009, 7, e1000034. [CrossRef]

81. Andronesi, O.C.; von Bergen, M.; Biernat, J.; Seidel, K.; Griesinger, C.; Mandelkow, E.; Baldus, M. Characterization of Alzheimer's-like paired helical filaments from the core domain of tau protein using solid-state NMR spectroscopy. J. Am. Chem. Soc. 2008, 130, 5922-5928. [CrossRef]

82. Wegmann, S.; Medalsy, I.D.; Mandelkow, E.; Muller, D.J. The fuzzy coat of pathological human Tau fibrils is a two-layered polyelectrolyte brush. Proc. Natl. Acad. Sci. USA 2013, 110, E313-E321. [CrossRef]

83. Mi, K.; Johnson, G.V. The role of tau phosphorylation in the pathogenesis of Alzheimer's disease. Curr. Alzheimer Res. 2006, 3, 449-463. [CrossRef] [PubMed]

84. Cuchillo-Ibanez, I.; Seereeram, A.; Byers, H.L.; Leung, K.Y.; Ward, M.A.; Anderton, B.H.; Hanger, D.P. Phosphorylation of tau regulates its axonal transport by controlling its binding to kinesin. FASEB J. 2008, 22, 3186-3195. [CrossRef] [PubMed]

85. Dixit, R.; Ross, J.L.; Goldman, Y.E.; Holzbaur, E.L. Differential regulation of dynein and kinesin motor proteins by tau. Science 2008, 319, 1086-1089. [CrossRef] [PubMed]

86. Knops, J.; Kosik, K.S.; Lee, G.; Pardee, J.D.; Cohen-Gould, L.; McConlogue, L. Overexpression of tau in a nonneuronal cell induces long cellular processes. J. Cell Biol. 1991, 114, 725-733. [CrossRef] [PubMed]

87. Caceres, A.; Kosik, K.S. Inhibition of neurite polarity by tau antisense oligonucleotides in primary cerebellar neurons. Nature 1990, 343, 461-463. [CrossRef]

88. Lee, G.; Newman, S.T.; Gard, D.L.; Band, H.; Panchamoorthy, G. Tau interacts with src-family non-receptor tyrosine kinases. J. Cell Sci. 1998, 111, 3167-3177.

89. Westerink, R.H.; Ewing, A.G. The PC12 cell as model for neurosecretion. Acta Physiol. 2008, 192, $273-285$. [CrossRef]

90. Sultan, A.; Nesslany, F.; Violet, M.; Begard, S.; Loyens, A.; Talahari, S. Nuclear tau, a key player in neuronal DNA protection. J. Biol. Chem. 2011, 286, 4566-4575. [CrossRef] [PubMed]

91. Violet, M.; Delattre, L.; Tardivel, M.; Sultan, A.; Chauderlier, A.; Caillierez, R. A major role for Tau in neuronal DNA and RNA protection in vivo under physiological and hyperthermic conditions. Front. Cell Neurosci. 2014, 8, 84. [CrossRef]

92. Marciniak, E.; Leboucher, A.; Caron, E.; Ahmed, T.; Tailleux, A.; Dumont, J. Tau deletion promotes brain insulin resistance. J. Exp. Med. 2017, 214, 2257-2269. [CrossRef] [PubMed]

93. De Felice, F.G.; Lourenco, M.V.; Ferreira, S.T. How does brain insulin resistance develop in Alzheimer's disease? Alzheimer's Dement. J. Alzheimer's Assoc. 2014, 10, S26-S32. [CrossRef]

94. Tian, H.; Davidowitz, E.; Lopez, P.; Emadi, S.; Moe, J.; Sierks, M. Trimeric tau is toxic to human neuronal cells at low nanomolar concentrations. Int. J. Cell Biol. 2013, 2013, 260787. [CrossRef]

95. Cowan, C.M.; Bossing, T.; Page, A.; Shepherd, D.; Mudher, A. Soluble hyper-phosphorylated tau causes microtubule breakdown and functionally compromises normal tau in vivo. Acta Neuropathol. 2010, 120, 593-604. [CrossRef]

96. Zempel, H.; Thies, E.; Mandelkow, E.; Mandelkow, E.M. Abeta oligomers cause localized Ca $\left({ }^{2+}\right)$ elevation, missorting of endogenous Tau into dendrites, Tau phosphorylation, and destruction of microtubules and spines. J. Neurosci. 2010, 30, 11938-11950, [published correction in: J. Neurosci. 2012, 32, 6052]. [CrossRef] 
97. Sahara, N.; Maeda, S.; Murayama, M.; Suzuki, T.; Dohmae, N.; Yen, S.H.; Takashima, A. Assembly of two distinct dimers and higher-order oligomers from full-length tau. Eur. J. Neurosci. 2007, 25, 3020-3029. [CrossRef]

98. Maeda, S.; Sahara, N.; Saito, Y.; Murayama, M.; Yoshiike, Y.; Kim, H.; Miyasaka, T.; Murayama, S.; Ikai, A.; Takashima, A. Granular tau oligomers as intermediates of tau filaments. Biochemistry 2007, 46, 3856-3861. [CrossRef]

99. Maeda, S.; Sahara, N.; Saito, Y.; Murayama, S.; Ikai, A.; Takashima, A. Increased levels of granular tau oligomers: An early sign of brain aging and Alzheimer's disease. Neurosci. Res. 2006, 54, 197-201. [CrossRef]

100. Cowan, C.M.; Mudher, A. Are tau aggregates toxic or protective in tauopathies? Front. Neurol. 2013, 4, 114. [CrossRef]

101. Trojanowski, J.Q.; Schmidt, M.L.; Shin, R.W.; Bramblett, G.T.; Rao, D.; Lee, V.M.Y. Altered tau and neurofilament proteins in neurodegenerative diseases: Diagnostic implications for Alzheimer's disease and Lewy body dementias. Brain Pathol. 1993, 3, 45-54. [CrossRef]

102. Mirbaha, H.; Holmes, B.B.; Sanders, D.W.; Bieschke, J.; Diamond, M.I. Tau Trimers Are the Minimal Propagation Unit Spontaneously Internalized to Seed Intracellular Aggregation. J. Biol. Chem. 2015, 290, 14893-14903. [CrossRef]

103. Patterson, K.R.; Remmers, C.; Fu, Y.; Brooker, S.; Kanaan, N.M.; Vana, L.; Ward, S.; Reyes, J.F.; Philibert, K.; Glucksman, M.J.; et al. Characterization of prefibrillar Tau oligomers in vitro and in Alzheimer disease. J. Biol. Chem. 2011, 286, 23063-23076. [CrossRef]

104. Makrides, V.; Shen, T.E.; Bhatia, R.; Smith, B.L.; Thimm, J.; Lal, R.; Feinstein, S.C. Microtubule-dependent oligomerization of tau. Implications for physiological tau function and tauopathies. J. Biol. Chem. 2003, 278, 33298-33304. [CrossRef]

105. Lasagna-Reeves, C.A.; Castillo-Carranza, D.L.; Guerrero-Muoz, M.J.; Jackson, G.R.; Kayed, R. Preparation and characterization of neurotoxic tau oligomers. Biochemistry 2010, 49, 10039-10041. [CrossRef]

106. Henkins, K.M.; Sokolow, S.; Miller, C.A.; Vinters, H.V.; Poon, W.W.; Cornwell, L.B.; Saing, T.; Gylys, K.H. Extensive p-tau pathology and SDS-stable p-tau oligomers in Alzheimer's cortical synapses. Brain Pathol. 2012, 22, 826-833. [CrossRef]

107. Soeda, Y.; Yoshikawa, M.; Almeida, O.F.; Sumioka, A.; Maeda, S.; Osada, H.; Kondoh, Y.; Saito, A.; Miyasaka, T.; Kimura, T.; et al. Toxic tau oligomer formation blocked by capping of cysteine residues with 1,2-dihydroxybenzene groups. Nat. Commun. 2015, 6, 10216. [CrossRef]

108. Kanemaru, K.; Takio, K.; Miura, R.; Titani, K.; Ihara, Y. Fetal-type phosphorylation of the tau in paired helical filaments. J. Neurochem. 1992, 58, 1667-1675. [CrossRef]

109. Kopke, E.; Tung, Y.C.; Shaikh, S.; Alonso, A.C.; Iqbal, K.; Grundke-Iqbal, I. Microtubule-associated protein tau. Abnormal phosphorylation of a non-paired helical filament pool in Alzheimer disease. J. Biol. Chem. 1993, 268, 24374-24384.

110. Smith, A.D. Imaging the progression of Alzheimer pathology through the brain. Proc. Natl. Acad. Sci. USA 2002, 99, 4135-4137. [CrossRef]

111. Zempel, H.; Luedtke, J.; Kumar, Y.; Biernat, J.; Dawson, H.; Mandelkow, E.; Mandelkow, E.M. Amyloid- $\beta$ oligomers induce synaptic damage via Tau-dependent microtubule severing by TTLL6 and spastin. Embo J. 2013, 32, 2920-2937. [CrossRef]

112. Gulisano, W.; Maugeri, D.; Baltrons, M.A.; Fà, M.; Amato, A.; Palmeri, A.; D'Adamio, L.; Grassi, C.; Devanand, D.P.; Honig, L.S.; et al. Role of Amyloid- $\beta$ and Tau Proteins in Alzheimer's Disease: Confuting the Amyloid Cascade. J. Alzheimers Dis. 2018, 64, S611-S631. [CrossRef]

113. Evans, D.B.; Rank, K.B.; Bhattacharya, K.; Thomsen, D.R.; Gurney, M.E.; Sharma, S.K. Tau phosphorylation at serine 396 and serine 404 by human recombinant tau protein kinase II inhibits tau's ability to promote microtubule assembly. J. Biol. Chem. 2000, 275, 24977-24983. [CrossRef]

114. Mondragon-Rodriguez, S.; Perry, G.; Luna-Munoz, J.; Acevedo-Aquino, M.C.; Williams, S. Phosphorylation of tau protein at sites Ser(396-404) is one of the earliest events in Alzheimer's disease and Down syndrome. Neuropathol. Appl. Neurobiol. 2014, 40, 121-135. [CrossRef]

115. Arrasate, M.; Pérez, M.; Valpuesta, J.M.; Avila, J. Role of glycosaminoglycans in determining the helicity of paired helical filaments. Am. J. Pathol. 1997, 151, 1115-1122. [CrossRef] 
116. Huvent, I.; Kamah, A.; Cantrelle, F.X.; Barois, N.; Slomianny, C.; Smet-Nocca, C.; Landrieu, I.; Lippens, G. A functional fragment of Tau forms fibers without the need for an intermolecular cysteine bridge. Biochem. Biophys. Res. Commun. 2014, 445, 299-303. [CrossRef]

117. Kim, A.C.; Lim, S.; Kim, Y.K. Metal Ion Effects on A $\beta$ and Tau Aggregation. Int. J. Mol. Sci. 2018, $19,128$. [CrossRef]

118. Zhu, H.L.; Meng, S.R.; Fan, J.B.; Chen, J.; Liang, Y. Fibrillization of human tau is accelerated by exposure to lead via interaction with His-330 and His-362. PLoS ONE 2011, 6, e25020. [CrossRef]

119. Pittman, A.M.; Fung, H.C.; de Silva, R. Untangling the tau gene association with neurodegenerative disorders. Hum. Mol. Genet. 2006, 15, R188-R195. [CrossRef]

120. Myers, A.J.; Pittman, A.M.; Zhao, A.S.; Rohrer, K.; Kaleem, M.; Marlowe, L.; Lees, A.; Leung, D.; McKeith, I.G.; Perry, R.H.; et al. The MAPT H1c risk haplotype is associated with increased expression of tau and especially of 4 repeat containing transcripts. Neurobiol. Dis. 2007, 25, 561-570. [CrossRef]

121. Oddo, S.; Caccamo, A.; Green, K.N.; Liang, K.; Tran, L.; Chen, Y.; Leslie, F.M.; LaFerla, F.M. Chronic nicotine administration exacerbates tau pathology in a transgenic model of Alzheimer's disease. Proc. Natl. Acad. Sci. USA 2005, 102, 3046-3051. [CrossRef]

122. Ribes, D.; Colomina, M.T.; Vicens, P.; Domingo, J.L. Effects of oral aluminum exposure on behavior and neurogenesis in a transgenic mouse model of Alzheimer's disease. Exp. Neurol. 2008, 214, 293-300. [CrossRef]

123. Walton, J.R. Evidence for participation of aluminum in neurofibrillary tangle formation and growth in Alzheimer's disease. J. Alzheimers Dis. 2010, 22, 65-72. [CrossRef]

124. Song, M.S.; Rauw, G.; Baker, G.B.; Kar, S. Memantine protects rat cortical cultured neurons against beta-amyloid-induced toxicity by attenuating tau phosphorylation. Eur. J. Neurosci. 2008, 28, 1989-2002. [CrossRef]

125. Aktas, O.; Ullrich, O.; Infante-Duarte, C.; Nitsch, R.; Zipp, F. Neuronal damage in brain inflammation. Arch. Neurol. 2007, 64, 185-189. [CrossRef]

126. Yoshiyama, Y.; Higuchi, M.; Zhang, B.; Huang, S.M.; Iwata, N.; Saido, T.C.; Maeda, J.; Suhara, T.; Trojanowski, J.Q.; Lee, V.M. Synaptic loss and microglial activation precede tangles in a P301S tauopathy mouse model. Neuron 2007, 53, 337-351. [CrossRef]

127. Mateo, I.; Sanchez-Juan, P.; Rodriguez-Rodriguez, E.; Infante, J.; Vázquez-Higuera, J.L.; García-Gorostiaga, I.; Berciano, J.; Combarros, O. Synergistic effect of Heme Oxygenase-1 and Tau genetic variants on Alzheimer's disease risk. Dement. Geriatr. Cogn. Disord. 2008, 26, 339-342. [CrossRef]

128. Beach, T.G.; Wilson, J.R.; Sue, L.I.; Newell, A.; Poston, M.; Cisneros, R.; Pandya, Y.; Esh, C.; Connor, D.J.; Sabbagh, M.; et al. Circle of Willis atherosclerosis: Association with Alzheimer's disease, neurotic plaques and neurofibrillary tangles. Acta Neuropathol. 2007, 113, 13-21. [CrossRef]

129. Michikawa, M. Role of cholesterol in amyloid cascade: Cholesterol-dependent modulation of tau phosphorylation and mitochondrial function. Acta Neurol. Scand. Suppl. 2006, 185, 21-26. [CrossRef]

130. Ohm, T.G.; Meske, V. Cholesterol, statins and tau. Acta Neurol. Scand. Suppl. 2006, 185, 93-101. [CrossRef]

131. Sontag, J.M.; Nunbhakdi-Craig, V.; Montgomery, L.; Arning, E.; Bottiglieri, T.; Sontag, E. Folate deficiency induces in vitro and mouse brain region-specific downregulation of leucine carboxyl methyltransferase-1 and protein phosphatase $2 \mathrm{~A} \mathrm{~B}$ (alpha) subunit expression that correlate with enhanced tau phosphorylation. J. Neurosci. 2008, 28, 11477-11487. [CrossRef]

132. Julien, C.; Tremblay, C.; Phivilay, A.; Berthiaume, L.; Emond, V.; Julien, P.; Calon, F. High-fat diet aggravates amyloid-beta and tau pathologiges in the 3xTg-AD mouse model. Neurobiol. Aging 2010, 31, 1516-1531. [CrossRef]

133. Rapp, M.A.; Schnaider-Beeri, M.; Grossman, H.T.; Sano, M.; Perl, D.P.; Purohit, D.P.; Gorman, J.M.; Haroutunian, V. Increased hippocampal plaques and tangles in patients with Alzheimer disease with a lifetime history of major depression. Arch. Gen. Psychiatry 2006, 63, 161-167. [CrossRef] [PubMed]

134. Rapp, M.A.; Schnaider-Beeri, M.; Purohit, D.P.; Perl, D.P.; Haroutunian, V.; Sano, M. Increased neurofibrillary tangles in patients with Alzheimer disease with comorbid depression. Am. J. Geriatr. Psychiatry 2008, 16, 168-174. [CrossRef] [PubMed]

135. Green, K.N.; Billing, L.M.; Roozendaal, B.; McGaugh, J.L.; LaFerla, F.M. Glucocorticoids increase amyloid-beta and tau pathology in a mouse model of Alzheimer's disease. J. Neurosci. 2006, 26, 9047-9056. [CrossRef] [PubMed] 
136. Braak, H.; Braak, E. Neuropathological stageing of Alzheimer-related changes. Acta Neuropathol. 1991, 82, 239-259. [CrossRef] [PubMed]

137. Serrano-Pozo, A.; Frosch, M.P.; Masliah, E.; Hyman, B.T. Neuropathological alterations in Alzheimer disease. Cold Spring Harb. Perspect. Med. 2011, 1, a006189. [CrossRef] [PubMed]

138. Braak, H.; Braak, E.; Grundke-Iqbal, I.; Iqbal, K. Occurence of neuropil threads in the senile human brains in Alzheimer's disease: A third location of paired helicial filaments outside of neurofibrillary tangles and neuritic plaques. Neurosci. Lett. 1986, 65, 351-355. [CrossRef]

139. Perry, G.; Kawai, M.; Tabaton, M.; Onorato, M.; Mulvihill, P.; Richey, P.; Morandi, A.; Connolly, J.A.; Gambetti, P. Neuropil threads of Alzheimer's disease show a marked alteration of the normal cytoskeleton. J. Neurosci. 1991, 11, 1748-1755. [CrossRef]

140. Wittmann, C.W.; Wszolek, M.F.; Shulman, J.M.; Salvaterra, P.M.; Lewis, J.; Hutton, M.; Feany, M.B. Tauopathy in Drosophila: Neurodegeneration without neurofibrillary tangles. Science 2001, 293, 711-714. [CrossRef] [PubMed]

141. Mershin, A.; Pavlopoulos, E.; Fitch, O.; Braden, B.C.; Nanopoulos, D.V.; Skoulakis, E.M. Learning and memory deficits upon TAU accumulation in Drosophila mushroom body neurons. Learn. Mem. 2004, 11, 277-287. [CrossRef] [PubMed]

142. Ishihara, T.; Zhang, B.; Higuchi, M.; Yoshiyama, Y.; Trojanowski, J.Q.; Lee, V.M. Age-dependent induction of congophilic neurofibrillary tau inclusions in tau transgenic mice. Am. J. Pathol. 2001, 158, 555-562. [CrossRef]

143. Frandemiche, M.L.; De Seranno, S.; Rush, T.; Borel, E.; Elie, A.; Arnal, I.; Lanté, F.; Buisson, A. Activity-dependent tau protein translocation to excitatory synapse is disrupted by exposure to amyloid-beta oligomers. J. Neurosci. 2014, 34, 6084-6097. [CrossRef] [PubMed]

144. Ittner, L.M.; Ke, Y.D.; Delerue, F.; Bi, M.; Gladbach, A.; van Eersel, J.; Wölfing, H.; Chieng, B.C.; Christie, M.J.; Napier, I.A.; et al. Dendritic function of tau mediates amyloid- $\beta$ toxicity in Alzheimer's disease mouse models. Cell 2010, 142, 387-397. [CrossRef] [PubMed]

145. Santacruz, K.; Lewis, J.; Spires, T.; Paulson, J.; Kotilinek, L.; Ingelsson, M.; Guimaraes, A.; DeTure, M.; Ramsden, M.; McGowan, E.; et al. Tau suppression in a neurodegenerative mouse model improves memory function. Science 2005, 309, 476-481. [CrossRef] [PubMed]

146. Van der Jeugd, A. Cognitive defects are reversible in inducible mice expressing pro-aggregant full-length human Tau. Acta Neuropathol. 2012, 123, 787-805. [CrossRef] [PubMed]

147. Lasagna-Reeves, C.A.; Castillo-Carranza, D.L.; Sengupta, U.; Clos, A.L.; Jackson, G.R.; Kayed, R. Tau oligomers impair memory and induce synaptic and mitochondrial dysfunction in wild-type mice. Mol. Neurodegener. 2011, 6, 39. [CrossRef] [PubMed]

148. Flach, K.; Hilbrich, I.; Schiffmann, A.; Gartner, U.; Kruger, M.; Leonhardt, M.; Waschipky, H.; Wick, L.; Arendt, T.; Holzer, M. Tau oligomers impair artificial membrane integrity and cellular viability. J. Biol. Chem. 2012, 287, 43223-43233. [CrossRef]

149. Mufson, E.J.; Ward, S.; Binder, L. Prefibrillar tau oligomers in mild cognitive impairment and Alzheimer's Disease. Neurodegener. Dis. 2013, 13, 151-153. [CrossRef]

150. Violet, M.; Chauderlier, A.; Delattre, L.; Tardivel, M.; Chouala, M.S.; Sultan, A. Prefibrillar Tau oligomers alter the nucleic acid protective function of Tau in hippocampal neurons in vivo. Neurobiol. Dis. 2015, 82, 540-551. [CrossRef]

151. Mansuroglu, Z.; Benhelli-Mokrani, H.; Marcato, V.; Sultan, A.; Violet, M.; Chauderlier, A.; Delattre, L.; Loyens, A.; Talahari, S.; Bégard, S.; et al. Loss of Tau protein affects the structure, transcription and repair of neuronal pericentromeric heterochromatin. Sci. Rep. 2016, 6, 33047. [CrossRef]

152. Chin, J.; Scharfman, H.E. Shared cognitive and behavioral impairments in epilepsy and Alzheimer's disease and potential underlying mechanisms. Epilepsy. Behav. 2013, 26, 343-351. [CrossRef]

153. Palop, J.J.; Mucke, L. Epilepsy and cognitive impairments in Alzheimer disease. Arch. Neurol. 2009, 66, 435-440. [CrossRef] [PubMed]

154. DeVos, S.L.; Goncharoff, D.K.; Chen, G.; Kebodeaux, C.S.; Yamada, K.; Stewart, F.R.; Schuler, D.R.; Maloney, S.E.; Wozniak, D.F.; Rigo, F.; et al. Antisense reduction of tau in adult mice protects against seizures. J. Neurosci. 2013, 33, 12887-12897. [CrossRef] [PubMed]

155. Gheyara, A.L.; Ponnusamy, R.; Djukic, B.; Craft, R.J.; Ho, K.; Guo, W.; Finucane, M.M.; Sanchez, P.E.; Mucke, L. Tau reduction prevents disease in a mouse model of Dravet syndrome. Ann. Neurol. 2014, 76, 443-456. [CrossRef] [PubMed] 
156. Kimura, T.; Whitcomb, D.J.; Jo, J.; Regan, P.; Piers, T.; Heo, S. Microtubule-associated protein tau is essential for long-term depression in the hippocampus. Philos. Trans. R. Soc. Lond. B Biol. Sci. 2013, 369, 20130144. [CrossRef] [PubMed]

157. Tai, H.C.; Wang, B.Y.; Serrano-Pozo, A.; Frosch, M.P.; Spires-Jones, T.L.; Hyman, B.T. Frequent and symmetric deposition of misfolded tau oligomers within presynaptic and postsynaptic terminals in Alzheimer's disease. Acta Neuropathol. Commun. 2014, 2, 146. [CrossRef] [PubMed]

158. Lasagna-Reeves, C.A.; Castillo-Carranza, D.L.; Sengupta, U.; Guerrero-Munoz, M.J.; Kiritoshi, T.; Neugebauer, V.; Jackson, G.R.; Kayed, R. Alzheimer brain-derived tau oligomers propagate pathology from endogenous tau. Sci. Rep. 2012, 2, 700. [CrossRef] [PubMed]

159. Morozova, O.A.; March, Z.M.; Robinson, A.S.; Colby, D.W. Conformational features of tau fibrils from Alzheimer's disease brain are faithfully propagated by unmodified recombinant protein. Biochemistry 2013, 52, 6960-6967. [CrossRef]

160. Gendreau, K.L.; Hall, G.F. Tangles, Toxicity, and Tau Secretion in AD-New Approaches to a Vexing Problem. Front. Neurol. 2013, 4, 160. [CrossRef]

161. Dubois, B.; Feldman, H.H.; Jacova, C.; Dekosky, S.T.; Barberger-Gateau, P.; Cummings, J.; Delacourte, A.; Galasko, D.; Gauthier, S.; Jicha, G.; et al. Research criteria for the diagnosis of Alzheimer's disease: Revising the NINCDS-ADRDA criteria. Lancet. Neurol. 2007, 6, 734-746. [CrossRef]

162. McKhann, G.M.; Knopman, D.S.; Chertkow, H.; Hyman, B.T.; Jack, C.R., Jr.; Kawas, C.H.; Klunk, W.E.; Koroshetz, W.J.; Manly, J.J.; Mayeux, R.; et al. The diagnosis of dementia due to Alzheimer's disease: Recommendations from the National Institute on Aging-Alzheimer's Association workgroups on diagnostic guidelines for Alzheimer's disease. Alzheimers Dement. 2011, 7, 263-269. [CrossRef]

163. Albert, M.S.; DeKosky, S.T.; Dickson, D.; Dubois, B.; Feldman, H.H.; Fox, N.C.; Gamst, A.; Holtzman, D.M.; Jagust, W.J.; Petersen, R.C.; et al. The diagnosis of mild cognitive impairment due to Alzheimer's disease: Recommendations from the National Institute on Aging-Alzheimer's Association workgroups on diagnostic guidelines for Alzheimer's disease. Alzheimers Dement. 2011, 7, 270-279. [CrossRef] [PubMed]

164. Olsson, B.; Lautner, R.; Andreasson, U.; Öhrfelt, A.; Portelius, E.; Bjerke, M.; Hölttä, M.; Rosén, C.; Olsson, C.; Strobel, G.; et al. CSF and blood biomarkers for the diagnosis of Alzheimer's disease: A systematic review and meta-analysis. Lancet Neurol. 2016, 15, 673-684. [CrossRef]

165. Tian, H.; Davidowitz, E.; Lopez, P.; He, P.; Schulz, P.; Moe, J.; Sierks, M.R. Isolation and characterization of antibody fragments selective for toxic oligomeric tau. Neurobiol. Aging 2015, 36, 1342-1355. [CrossRef] [PubMed]

166. Sengupta, U.; Portelius, E.; Hansson, O.; Farmer, K.; Castillo-Carranza, D.; Woltjer, R.; Zetterberg, H.; Galasko, D.; Blennow, K.; Kayed, R. Tau oligomers in cerebrospinal fluid in Alzheimer's disease. Ann. Clin. Transl. Neurol. 2017, 4, 226-235. [CrossRef] [PubMed]

167. Brkic, M.; Balusu, S.; Wonterghem, E.V.; Gorle, N.; Benilova, I.; Kremer, A.; Hove, I.V.; Moons, L.; Strooper, B.D.; Kanazir, S.; et al. Amyloid oligomers disrupt blood-CSF barrier integrity by activating matrix metalloproteinases. J. Neurosci. 2015, 35, 12766-12778. [CrossRef] [PubMed]

168. Williams, S.M.; Schulz, P.; Rosenberry, T.L.; Caselli, R.J.; Sierks, M.R. Blood-Based Oligomeric and Other Protein Variant Biomarkers to Facilitate Pre-Symptomatic Diagnosis and Staging of Alzheimer's Disease. J. Alzheimers Dis. 2017, 58, 23-35. [CrossRef] [PubMed]

169. Kolarova, M.; Sengupta, U.; Bartos, A.; Ricny, J.; Kayed, R. Tau Oligomers in Sera of Patients with Alzheimer's Disease and Aged Controls. J. Alzheimers Dis. 2017, 58, 471-478. [CrossRef] [PubMed]

(C) 2019 by the authors. Licensee MDPI, Basel, Switzerland. This article is an open access article distributed under the terms and conditions of the Creative Commons Attribution (CC BY) license (http://creativecommons.org/licenses/by/4.0/). 